\title{
O novo constitucionalismo e a judicialização da política pura no mundo*
}

Ran Hirschl**

\section{Introdução}

Nas últimas décadas, o mundo testemunhou uma profunda transferência de poder de instituições representativas para tribunais, tanto domésticos, quanto supranacionais. O conceito de supremacia constitucional - que há muito tempo é um pilar central da ordem política norte-americana ${ }^{1}$ - é hoje compartilhado, de uma maneira ou de outra, por mais de 100 países ao redor do mundo. Diversos regimes pós-autoritários no antigo Bloco Oriental, no sul da Europa, na América Latina e na Ásia rapidamente adotaram princípios do constitucionalismo moderno durante suas transições para a democracia. Até mesmo países como o Canadá, Israel, Reino Unido e Nova Zelândia - há pouco tempo descritos como os últimos bastiões da soberania parlamentar no estilo Westminster ${ }^{2}$ - gradualmente embarcaram na onda global rumo à constitucionalização. A imprensa cobre quase

\footnotetext{
* Publicado originalmente como "The new constitutionalism and the judicialization of pure politics worldwide", Fordham Law Review, v. 75, n. 2, 2006. Traduzido por Diego Werneck Arguelhes e Pedro Jimenez Cantisano.

** Professor de ciência política e direito, Universidade de Toronto.

${ }^{1}$ N. do T. Traduzimos a expressão "American" por "norte-americana(o)".

${ }^{2} \mathrm{~N}$. do T. No original, "Westminster-style parliamentary democracy". O autor está se referindo a um modelo de democracia parlamentarista majoritária, na qual o governo é completamente ocupado pelo partido vencedor das eleições. O exemplo paradigmático é o Reino Unido, cujo Parlamento se reúne no Palácio de Westminster.
} 
diariamente questões como processos de constitucionalização na União Europeia (UE) e no Iraque, julgamentos de ditadores depostos perante tribunais internacionais e a tomada de importantes decisões constitucionais nos Estados Unidos, na Alemanha e na África do Sul.

Uma das principais manifestações dessa tendência tem sido a judicialização da política - o recurso cada vez maior a tribunais e a meios judiciais para o enfrentamento de importantes dilemas morais, questões de política pública e controvérsias políticas. Com recém-adquiridos mecanismos de controle de constitucionalidade, tribunais superiores ao redor do mundo têm sido frequentemente chamados a resolver uma série de problemas - da extensão das liberdades de culto religioso e de expressão, dos direitos à igualdade e à privacidade e da liberdade de reprodução, a políticas públicas relacionadas à justiça criminal, à propriedade, ao comércio, à educação, à imigração, ao trabalho e à proteção ambiental. Manchetes sensacionalistas sobre decisões judiciais importantes a respeito de temas controversos - casamento entre pessoas do mesmo sexo, limites para o financiamento de campanhas e ações afirmativas, para dar apenas alguns exemplos - tornaram-se fenômeno comum. Isso está evidente nos Estados Unidos, onde o legado do controle de constitucionalidade acabou de atingir seu bicentenário. Aqui, os tribunais estão há muito tempo exercendo um papel significativo na elaboração de políticas públicas. Mas está igualmente evidente em democracias constitucionais mais jovens, que só estabeleceram mecanismos de controle de constitucionalidade nas últimas décadas. Enquanto isso, tribunais internacionais se tornaram o locus central de coordenação de políticas públicas em níveis global e regional, de assuntos comerciais e monetários a condições de trabalho e regulamentações ambientais.

Entretanto, a crescente importância política dos tribunais tem não apenas se tornado mais abrangente, mas também se expandido em escopo, transformando-se assim em um fenômeno diverso, multifacetado, que vai muito além do conceito - que se tornou corrente - de elaboração de políticas públicas por juízes, por meio de decisões sobre direitos e da remarcação judicial das fronteiras entre órgãos do Estado. A judicialização da política agora inclui a transferência massiva, para os tribunais, de algumas das mais centrais e polêmicas controvérsias políticas em que uma democracia pode se envolver. Lembremo-nos de episódios como o resultado das eleições presidenciais de 2000 nos Estados Unidos, a nova ordem constitucional na África do Sul, o lugar da Alemanha na União Europeia, a guerra na Chechênia, a política econômica na Argentina, o regime de bem-estar social na Hungria, o golpe de Estado militar liderado por Pervez Musharraf no Paquistão, dilemas de justiça transicional na América Latina pós-autoritária e na Europa pós-comunista, a natureza secular 
do sistema político turco, a definição fundamental de Israel como um "Estado judeu e democrático", ou o futuro político de Quebec e da federação canadense: todos esses e muitos outros problemas políticos altamente controversos foram articulados como problemas constitucionais. E isso tem sido acompanhado pela suposição de que os tribunais - e não os políticos, nem a própria população - seriam os fóruns apropriados para a tomada dessas cruciais decisões. Para resumir, e parafraseando a observação de Alexis de Tocqueville (1961) sobre os Estados Unidos, não há no mundo do novo constitucionalismo quase nenhum dilema de política pública ou desacordo político que não se torne, cedo ou tarde, um problema judicial.

Apesar da crescente prevalência desse fenômeno, o discurso acadêmico sobre a judicialização da política ao redor do mundo permanece surpreendentemente superficial. Com poucas e notáveis exceções, ${ }^{3}$ a judicialização da política é habitualmente tratada de maneira muito pouco refinada, como um resultado natural da prevalência do discurso dos direitos fundamentais. Às vezes, a judicialização da política é confundida com uma versão genérica do ativismo judicial, prestando-se pouca ou nenhuma atenção à diferença entre atribuir aos tribunais a definição do escopo do direito a um julgamento justo, por exemplo, e confiar a eles a solução de delicadas questões de identidade coletiva que se encontram no coração dos processos de construção da nação. Neste artigo, procuro mapear os contornos do segundo aspecto da judicialização, que poderíamos chamar de judicialização da megapolítica ou da política pura. Começo distinguindo três categorias abrangentes de judicialização: a disseminação de discursos, jargões, regras e procedimentos jurídicos na esfera política e nos fóruns e processos de elaboração de políticas públicas; a judicialização da elaboração de políticas públicas pelas formas "comuns" de controle judicial de constitucionalidade de leis e atos da administração pública; e a judicialização da "política pura" - a transferência, para os tribunais, de assuntos cuja natureza e significado são claramente políticos, incluindo importantes debates sobre a legitimidade de regimes e identidades coletivas que definem (e muitas vezes dividem) comunidades inteiras. Em seguida, procuro ilustrar as características que distinguem o último tipo de judicialização com exemplos da jurisprudência política de cortes e tribunais ao redor do mundo. Na última parte, procuro mostrar a importância do apoio da esfera política como condição necessária para a judicialização da política pura. Estes exemplos sugerem que o direito constitucional é, de fato, uma forma de política por outros meios.

\footnotetext{
${ }^{3}$ Ver Tate e Vallinder (1995); Hirschl (2004); Sieder et al. (2005); Shapiro e Sweet (2002); Ferejohn, (2002); Hirschl (2002); Pildes (2004).
} 


\section{As três faces da política judicializada}

"Judicialização da política" é um termo "guarda-chuva", comumente usado para abranger o que, na verdade, são três processos inter-relacionados. De forma mais abstrata, a judicialização da política se refere à disseminação de discursos, jargões, regras e processos jurídicos na esfera política e nos fóruns e processos de elaboração de políticas públicas. A predominância do discurso jurídico e a popularização do jargão jurídico são evidentes em praticamente todos os aspectos da vida moderna. Talvez a melhor ilustração dessa predominância seja a subordinação, em comunidades modernas organizadas como estados de direito, de quase todo fórum decisório a normas e procedimentos quase judiciais. Temas que antes eram negociados de maneira informal ou não judicial, agora são dominados por regras e procedimentos jurídicos. ${ }^{4}$

Esse tipo de judicialização é inseparável do fenômeno da captura das relações sociais e da cultura popular e da expropriação dos conflitos sociais por parte do direito. Origina-se da crescente complexidade e contingência das sociedades modernas, ${ }^{5}$ ou da criação e expansão do estado de bem-estar social moderno e suas numerosas agências reguladoras. Algumas análises do rápido crescimento da judicialização no âmbito judicial supranacional a descrevem como uma resposta institucional inevitável aos complexos problemas de coordenação gerados pela necessidade sistêmica, em uma era de mercados econômicos convergentes, de se adotar normas jurídicas e regulamentações administrativas padronizadas entre os estados-membros desses mercados. ${ }^{6}$

Outros aspectos deste tipo de "juridificação" da vida moderna foram identificados pelos primeiros sociólogos do direito - por exemplo, a tese de Henry Maine sobre a passagem do "status ao contrato", 7 ou a ênfase dada por Max Weber ao surgimento de um sistema jurídico formal, claro e racional, nas sociedades ocidentais. ${ }^{8}$ Os advogados são os mais importantes agentes desse tipo de "judicialização orgânica". De acordo com Emile Durkheim, por exemplo, o direito reflete a divisão do trabalho e a solidariedade interpessoal em evolução em uma dada sociedade. ${ }^{9}$ Em sociedades primitivas, argumenta Durkheim, a divisão do trabalho entre as pessoas era menos desenvolvida e os vínculos sociais eram mais fortes. Assim, o direito formal não era necessário. Em sociedades mais desenvolvidas, o grau de especialização é maior e há uma divisão do trabalho mais clara entre as

\footnotetext{
4 Ver Sieder (2005).

${ }^{5}$ Ver Luhmann (1985).

${ }^{6}$ Ver Sweet e Brunell (1998) e Sweet (2000).

${ }^{7}$ Maine (2001).

${ }^{8}$ Ver Weber (1968).

${ }^{9}$ Ver Durkheim (1964).
} 
pessoas, acompanhada de menor coesão social. O contrato, em vez do status ou do escambo, torna-se a principal forma de troca entre as pessoas. $\mathrm{O}$ aparato estatal deve agora assegurar o cumprimento dos contratos e estabelecer as condições externas para seu uso. Uma classe especial de pessoas - os advogados - surge para negociar e litigar essas relações contratuais mais complexas e cada vez mais presentes na sociedade moderna.

O segundo, e mais concreto, aspecto da judicialização da política é a expansão da competência de tribunais e juízes quanto à definição de políticas públicas, principalmente por meio de decisões envolvendo direitos constitucionais e da remarcação judicial dos limites entre órgãos do estado (separação de poderes, federalismo). A cada semana, alguma corte suprema em algum lugar do mundo anuncia uma decisão importante sobre o escopo da proteção a direitos constitucionais ou sobre os limites dos poderes Legislativo e Executivo. Os casos mais comuns envolvem liberdades civis clássicas. São primordialmente sobre garantias de devido processo legal na esfera criminal ou sobre aspectos variados dos direitos à privacidade e à igualdade formal - todos eles no sentido de expandir e reforçar as fronteiras da proteção constitucional à esfera individual, geralmente tida como ameaçada pela longa e invasiva mão da regulação estatal. ${ }^{10}$

Talvez a face mais evidente da judicialização da elaboração de políticas públicas por meio de decisões sobre direitos fundamentais possa ser encontrada no âmbito da justiça processual. ${ }^{11}$ Em muitos países alinhados ao novo constitucionalismo, casos de devido processo penal representam 2/3 do universo total de casos envolvendo direitos nos tribunais constitucionais. ${ }^{12}$ A prevalência do direito ao devido processo legal também é evidente nos casos envolvendo a adoção de procedimentos legais mais "flexibilizados" no combate ao terrorismo. Em 1999, a Suprema Corte de Israel baniu o uso da tortura em interrogatórios conduzidos pelo Serviço Geral de Segurança Israelense. ${ }^{13}$ Em 2002, o Conselho Constitucional do Peru anulou o julgamento secreto, por um tribunal militar, de líderes do movimento rebelde maoísta Sendero Luminoso. ${ }^{14}$ A Câmara dos Lordes declarou inconstitucional a legislação britânica sobre o estado de emergência pós-11 de setembro. ${ }^{15}$

\footnotetext{
${ }^{10}$ Hirschl, 2004:103-118.

${ }^{11}$ N. do T. No original, procedural justice. Hirschl refere-se aqui às decisões judiciais que examinam a correção de procedimentos estatais nos quais o cidadão é parte, em qualquer área do direito. No entanto, optou-se por evitar o termo "procedimental" que, como qualificativo de "justiça", poderia causar confusão com a ideia de concepções procedimentais de justiça.

${ }^{12}$ Hirschl, 2004:103-118.

${ }^{13}$ Ver HCJ 5100/94. Pub. comm. against torture. Isr. v. State of Isr, IsrSC, v. 53, n. 4, p. 817, 836, 838, 340, 1999.

${ }^{14}$ Retrial for Peru shining path rebel, BBC News, 21 nov. 2002. Disponível em: <http://news.bbc.co.uk/2/hi/ americas/2497359.stm >. Acesso em: 15 out. 2006.

${ }^{15}$ Ver A and others $v$. Sec'y of State for the Home Dep't, X and another $v$. Sec'y of State for the Home Dep't, (2004) UKHL 56, (2005) 2 W.L.R. 87.
} 
Na recente decisão Hamdan $v$. Rumsfeld, a Suprema Corte dos EUA suprimiu os tribunais militares do governo Bush na Baía de Guantánamo. ${ }^{16}$

Enquanto o primeiro tipo de judicialização pode ser descrito como "judicialização das relações sociais", a judicialização do segundo tipo enfoca principalmente a justiça processual e a equidade formal em processos decisórios. Na medida em que é muitas vezes iniciada por pessoas comuns invocando direitos para se opor a políticas, decisões e práticas do Estado, pode também ser descrita como "judicialização vinda de baixo". Como sugerido por Charles Epp, o impacto da adoção de catálogos de direitos fundamentais pode ser limitado pela impossibilidade de os indivíduos invocarem efetivamente esses direitos por meio de litigância estratégica. ${ }^{17,18}$. Assim, listas de direitos fundamentais importam na medida em que haja uma estrutura de suporte à mobilização jurídica - um nexo de organizações da sociedade civil, advogados, faculdades de direito, agências governamentais executivas e serviços de assistência jurídica que promovam esses direitos. Em outras palavras, se, por um lado, a positivação no texto constitucional é condição necessária para a proteção efetiva de direitos e liberdades; por outro, certamente não é condição suficiente. A capacidade desses dispositivos de semear mudanças sociais em uma comunidade depende da existência de uma estrutura de suporte à mobilização jurídica da sociedade civil e, de forma mais geral, de condições socioculturais adequadas a essa "judicialização vinda de baixo".

A mobilização jurídica "vinda de baixo" é favorecida pela frequente crença de que direitos judicialmente protegidos operam como forças autoimplementáveis de mudança social - isto é, forças que não dependem das restrições a que todo poder político está sujeito. Essa crença tem hoje um status quase sagrado no debate público. O "mito dos direitos", como denominado por Stuart Scheingold, procura chamar a nossa atenção para o contraste entre o caráter aberto dos procedimentos judiciais e as barganhas secretas dos grupos de interesse na esfera política, reforçando assim a imagem de integridade e incorruptibilidade do processo judicial. ${ }^{19}$ "O objetivo, claro, é tornar mais atrante o uso de soluções legais e constitucionais para problemas políticos".$^{20}$ Por outro lado, isso pode levar à expansão de um "discurso de direitos" populista e ao correspondente empobrecimento do discurso político. ${ }^{21}$

\footnotetext{
${ }^{16}$ Hamdan $v$. Rumsfeld, 126 S. Ct. 2749 (2006).

${ }^{17}$ Ver Epp (1988).

${ }^{18} \mathrm{~N}$. do T. No original, strategic litigation. O autor se refere aqui ao recurso sistemático e planejado aos tribunais, por parte de movimentos sociais e organizações da sociedade civil, no sentido de obter pela via judicial a proteção de determinados interesses ou a promoção de certas agendas políticas.

${ }^{19}$ Ver Scheingold (2004).

${ }^{20}$ Idem, p. 34.

${ }^{21}$ Ver Glendon (1991).
} 
Outro aspecto da segunda face da judicialização é a promoção de justiça processual por meio do controle judicial de atos administrativos. A proliferação de agências administrativas no moderno estado de bem-estar social expandiu profundamente a extensão do poder dos juízes de rever atos da administração pública. Na maioria das vezes, esse envolvimento judicial na elaboração de políticas públicas fica restrito a aspectos procedimentais, ou seja, concentra-se no processo e não na substância. Partindo de princípios básicos de direito contratual, constitucional e, principalmente, administrativo, os tribunais monitoram e promovem a aplicação de garantias do devido processo legal, igualdade de oportunidades, transparência, accountability e razoabilidade na elaboração de políticas públicas. Portanto, não surpreende que esse tipo de judicialização domine o próprio sistema judicial, do processo civil ao criminal - e de que seja particularmente visível em áreas do direito com um grande componente processual, como imigração, direito tributário e contratos administrativos. Mas esse tipo de judicialização também é claramente visível em incontáveis áreas, de planejamento urbano e saúde pública a relações industriais e proteção ao consumidor. Os tribunais também têm monitorado aspectos importantes da privatização de patrimônio estatal no mundo póscomunista. Em síntese, seja por meio da jurisprudência centrada em direitos fundamentais, seja por meio da revisão judicial de atos administrativos, na maioria das democracias constitucionais de hoje a judicialização da elaboração de políticas públicas se aproxima de um verdadeiro "governo com juízes". 22, 23

Nas últimas décadas, a judicialização da elaboração de políticas públicas também se expandiu internacionalmente, com o estabelecimento de numerosas cortes e tribunais, painéis e comissões internacionais quase judiciais, que lidam com direitos humanos, governança transnacional, comércio e assuntos monetários. ${ }^{24}$ Talvez em nenhum lugar esse processo seja mais evidente do que na Europa. ${ }^{25} \mathrm{Um}$ processo similar aconteceu no âmbito das disputas de comércio internacional. ${ }^{26}$ Decisões do mecanismo de solução de controvérsias da Organização Mundial do Comércio (OMC) tiveram extensas implicações para políticas de troca e comércio no mundo. Esse também é o caso dos Estados Unidos, onde defender o cumprimento de decisões desfavoráveis de tribunais estrangeiros é sempre uma árdua tarefa. O Tratado de Livre Comércio da América do Norte (Nafta), de 1994, também estabelece processos quase judiciais de solução de controvérsias envolvendo

\footnotetext{
${ }^{22}$ Ver Guarnieri e Pederzoli (2002).

${ }^{23} \mathrm{~N}$. do T. No original, government with judges. O uso da preposição "with" aqui é intencionalmente ambíguo, podendo significar tanto governo com juízes (isto é, ao lado, junto com, convivendo com), quanto governo por meio de juízes (tendo os juízes como instrumento de governança).

${ }^{24}$ Ver Goldstein et al. (2001); Romano (1999) e Slaughter (2000).

${ }^{25}$ Ver Alter (2001); Sweet (2000) e Weiler (1999).

${ }^{26}$ Goldstein et al., 2001.
} 
investimentos estrangeiros, serviços financeiros e instâncias antidumping e compensação. Arranjos similares foram estabelecidos pelo Mercado Comum do Sul (Mercosul), na América do Sul, e pela Associação das Nações do Sudeste Asiático (Asean) na região da Ásia-Pacífico. Em resumo, nas últimas décadas, estabeleceuse rapidamente uma transferência, em larga escala, de prerrogativas centrais de elaboração de políticas de arenas decisórias majoritárias em nível nacional para entidades e tribunais transnacionais relativamente insulados.

Uma terceira classe emergente de judicialização da política é o emprego de tribunais e juízes para lidar com o que podemos chamar de "megapolítica": controvérsias políticas centrais que definem (e muitas vezes dividem) comunidades inteiras. A judicialização da megapolítica inclui algumas subcategorias: judicialização de processos eleitorais; supervisão judicial de prerrogativas do Poder Executivo em áreas de planejamento macroeconômico ou segurança nacional (o fim daquilo que é conhecido na teoria constitucional como a doutrina da "questão política" ${ }^{27}$ dilemas fundamentais de justiça restautativa; ${ }^{28}$ corroboração judicial de transformações de regime político; e, acima de tudo, a judicialização da formação de identidades coletivas, processos de construção de nações e disputas a respeito da própria definição - ou raison d'être - da comunidade, talvez o tipo mais problemático de judicialização do ponto de vista da teoria constitucional. Essas áreas emergentes de política judicializada expandem as fronteiras do envolvimento de tribunais superiores nacionais na esfera política para além do âmbito dos direitos constitucionais ou do federalismo, levando a judicialização da política a um ponto que excede de longe qualquer limite previamente estabelecido. Na maioria das vezes, essa tendência é apoiada, tácita ou explicitamente, por poderosos agentes políticos. O resultado tem sido a transformação de cortes supremas no mundo inteiro em parte central dos aparatos nacionais para a elaboração de políticas pú-

\footnotetext{
${ }^{27}$ N. do T. No original, political question doctrine. A referência aqui é a um conjunto de standards adotados por tribunais em certos períodos da história constitucional dos EUA para demarcar os limites de sua competência para apreciar questões que, por sua natureza política, por expressa determinação legal/constitucional ou por questões prudenciais, devem ser resolvidas exclusivamente pelos poderes eleitos. Em um sentido mais geral, essa expressão é muitas vezes utilizada em textos de língua inglesa para designar qualquer posicionamento jurisprudencial adotado por tribunais para isolar certas questões como "políticas" e, portanto, insuscetíveis de apreciação judicial.

${ }^{28}$ N. do T. Ao longo do texto, Hirschl parece utilizar os termos reparative justice e restorative justice de forma intercambiável, referindo-se a questões envolvendo medidas a serem adotadas no sentido de compensar certos grupos ou indivíduos perseguidos ou que tiveram direitos sistematicamente violados em períodos anteriores (e geralmente sob outro regime político) da história do país, e/ou no sentido de reconciliar divisões internas dentro da comunidade após transições de regime. No texto, essas ideias também vêm associadas à categoria mais geral da justiça transicional (traduzido aqui como justiça transicional), que abrange o conjunto maior das medidas tomadas para se "passar" de forma justa de um regime político a outro. A categoria da justiça transicional é mais ampla por incluir também medidas não compensatórias, de caráter retributivo, como a punição de responsáveis por violações de direitos humanos durante o regime anterior.
} 
blicas. Em outra oportunidade, descrevi esse processo como uma transição para a juristocracia. ${ }^{29}$

Não se pode enfatizar demais a profundidade dessa transição. Enquanto a supervisão judicial dos aspectos procedimentais do processo democrático - monitoramento de procedimentos e regulamentações eleitorais, por exemplo - se enquadra na competência da maioria das cortes constitucionais, questões como a legitimidade de um regime político, a identidade coletiva de uma nação, ou o enfrentamento de um passado do qual a comunidade não se orgulha refletem dilemas que são primordialmente morais e políticos - e não jurídicos. Como tais, eles devem - ao menos por questão de princípio - ser contemplados e decididos pela própria população, por meio de seus representantes eleitos e politicamente responsabilizáveis. Julgar tais questões é um exercício inerente e substancialmente político, muito além da aplicação de dispositivos sobre direitos fundamentais e devido processo legal a questões de políticas públicas. Judicialização desse tipo coloca os tribunais na posição de decidir sobre alguma das mais centrais questões políticas que uma nação pode enfrentar, mesmo que a Constituição não faça nenhuma referência a esses problemas, e apesar de se reconhecer os óbvios riscos políticos envolvidos em decisões desse tipo. São precisamente essas situações de judicialização de questões que combinam altíssimos riscos políticos com instruções constitucionais escassas ou impertinentes que tornam mais questionáveis as credenciais democráticas do controle judicial de constitucionalidade. Isso ocorre porque não está nada claro o que tornaria os tribunais o fórum mais apropriado para resolver esses dilemas puramente políticos.

A diferença entre a segunda e a terceira face da judicialização é sutil, mas importante. Encontra-se, em parte, na distinção qualitativa entre questões primariamente de justiça processual, de um lado, e dilemas morais substantivos ou controvérsias políticas essenciais enfrentadas por toda a nação, de outro. Em outras palavras, parece haver uma diferença entre a importância política da judicialização da elaboração de políticas públicas e a importância política da judicialização da megapolítica. A garantia de justiça processual em contratações feitas com o Estado é um elemento importante se queremos ter uma administração pública livre de corrupção. Do mesmo modo, o alcance do direito a um julgamento rápido é uma questão importante para pessoas que estejam enfrentando acusações criminais. Mas sua relevância política não é tão significativa quanto a de questões como o lugar da Alemanha na União Europeia, o futuro de Quebec e da federação canadense, a constitucionalidade do acordo político pós-Apartheid na África do Sul, ou das ações afirmativas nos Estados Unidos.

\footnotetext{
${ }^{29}$ Hirschl, 2004:222-223.
} 
Entretanto, a diferença entre o segundo e o terceiro níveis de política judicializada vai além da relevância política das questões de que tratam. Depende da nossa própria conceituação do que é "político". O que conta como decisão "política" não é uma pergunta fácil de ser respondida. Uma decisão política afeta a vida de muitas pessoas. Porém, muitos casos que não são puramente políticos (grandes ações coletivas) também afetam as vidas de muitas pessoas. Mais ainda, já que não existe uma resposta simples e completa para a pergunta "o que é político?" - para muitos teóricos sociais, a resposta seria "tudo é político" -, também não pode haver uma definição simples e completa da judicialização da política. Em outras palavras, o que Larry King consideraria político é bem diferente do que Michel Foucault consideraria político. Do mesmo modo, o que pode ser considerado questão política controversa em uma comunidade (digamos, o direito de fazer um aborto nos Estados Unidos) pode não ser um problema em outra comunidade. Contudo, mesmo levando em conta essas considerações, parece haver uma diferença qualitativa entre a relevância política de, por exemplo, uma decisão judicial especificando os limites do direito a uma audiência justa perante o tribunal ou discutindo a validade de cotas federais para exportações agrícolas e a de um julgamento determinando a legitimidade de um regime ou a identidade coletiva de uma nação. De fato, poucas decisões podem ser consideradas mais "políticas" que a definição autoritativa da raison d'être de uma comunidade. Essa distinção nebulosa, ainda que intuitiva, é o que diferencia a judicialização da megapolítica dos dois primeiros níveis de judicialização. Consideremos os exemplos a seguir - todos são raramente abordados pela teoria constitucional em sua forma canônica, normalmente preocupada apenas com problemas norte-americanos.

\section{A judicialização da política pura: alguns casos ilustrativos}

\section{O cenário de Bush v. Gore}

Uma área politicamente sensível que passou por uma dramática judicialização nas últimas duas décadas é o processo eleitoral - ou o que pode ser chamado de o "direito da democracia". ${ }^{30}$ No mundo do novo constitucionalismo, tribunais são frequentemente chamados a decidir questões como remarcação de distritos eleitorais, financiamento de campanha de partidos políticos e propaganda eleitoral na televisão. Tribunais aprovam ou desqualificam partidos políticos e candidatos com cada vez mais frequência. Nos últimos anos, tribunais em diversas democra-

\footnotetext{
${ }^{30}$ Ver Issacharoff et al. (1998) e Miller (2004).
} 
cias constitucionais - especialmente na Bélgica, Israel, Índia, Espanha e Turquia - baniram (ou chegaram muito perto de banir) partidos políticos populares de eleições nacionais. ${ }^{31}$ Recentemente, a Suprema Corte de Bangladesh considerou inválidas as listas de eleitores que haviam sido feitas para as eleições seguintes. ${ }^{32}$ Apenas na última década, tribunais constitucionais em mais de 25 países foram chamados para determinar o futuro político de líderes políticos importantes por meio de processos de impeachment ou de desqualificação. Enquanto a Corte Constitucional Russa, por exemplo, impôs um limite constitucional à tentativa de terceiro mandato do presidente Boris Yeltsin, a Suprema Corte colombiana aprovou recentemente a constitucionalidade de uma emenda que removeu da Constituição a proibição de reeleição de oficiais governamentais, permitindo assim ao presidente Álvaro Uribe se candidatar e ser reeleito para um segundo mandato. ${ }^{33}$

Tribunais também se tornaram as últimas instâncias decisórias em disputas sobre resultados eleitorais nacionais - por exemplo, no Zimbábue (2002), ${ }^{34}$ em Taiwan (2004), , ${ }^{35}$ na Ucrânia (2004) ${ }^{36}$ e na Itália (2006), onde a Suprema Corte italiana aprovou uma vitória por menos de 25 mil votos do líder de centro-esquerda Romano Prodi sobre o direitista Silvio Berlusconi em uma das eleições mais disputadas daquele país. ${ }^{37}$ Mais recentemente, uma série de recursos e contrarrecursos eleitorais culminou na rejeição, pelo Tribunal Federal Eleitoral do México, da acusação de fraude nas eleições presidenciais de julho de 2006, feita pelo candidato esquerdista Andes Manuel Lopez Obrador. ${ }^{38}$ A decisão garantiu formalmente a presidência de 2006 a 2012 ao candidato de direita Felipe Calderón, após uma vitória eleitoral por uma margem de menos de 0,6\%. Até mesmo as exóticas nações insulares de Madagascar e Trinidad e Tobago tiveram o destino de suas eleições

\footnotetext{
${ }^{31}$ Pildes (2004:33). A Corte Suprema da Bélgica baniu o partido separatista conservador neerlandês Vlaams Blok em novembro de 2004. O partido ressurgiu como Vlaams Belang poucos meses depois.

${ }^{32}$ Courting danger: democracy in the lap of the judges. Economist, p. 40, June 2006.

${ }_{33}$ Uribe wins Colombia Court ruling, allowing him to seek second term. Bloomberg News Online, 19 Oct. 2005. Disponível em: <www.bloomberg.com/apps/news?pid=10000086\&sid=aaT.v1TYrNZ0>.

${ }^{34}$ Ver Legal resources found. Justice in Zimbabwe (report). Disponível em: <www.swradioafrica.com/Documents/RDC_report.htm>. Acesso em: 20 set. 2006.

${ }^{35}$ Ver Hogg (2004).

${ }^{36}$ Ver a decisão da Corte Constitucional ucraniana de dezembro de 2004 (invalidando os resultados da eleição presidencial de novembro de 2004 e ordenando uma nova eleição). Para a tradução para o inglês, ver: <www2.pravda.com.ua/en/archive/2004/december/3/5.shtml>; ver também a decisão da Corte Constitucional ucraniana de 24 de dezembro de 2004. Disponível em: <http://zakon.rada.gov. ua/cgibin/laws/main.cgi?nreg=v022p710\%2D04> (sobre a constitucionalidade do Ato das Eleições Presidenciais). A decisão da mesma Corte de 26 de dezembro de 2004. Disponível em: <http://zakon.rada. gov.ua/cgi-bin/laws/main.cgi?nreg=n0119700\%2D04> (respondendo à alegação de Victor Yanukoyvich sobre a violação dos direitos de eleitores deficientes durante as eleições de 2004).

${ }^{37}$ Ver Italian Court rules prodi election winner, Guardian Unlimited, 19 abr. 2006. Disponível em: <www. guardian.co.uk/italy/story/0,,1756970,00.html>.

${ }_{38}$ A decisão foi publicada no dia 4 de setembro de 2006. Ver Mexico Court rejects fraud claim, BBC News Online, 29 Aug. 2006. Disponível em: <http://news.bbc.co.uk/2/hi/americas/5293796.stm>. Para discussões mais profundas sobre a Corte Eleitoral Federal do México, ver Zamora (2004).
} 
determinado por tribunais. ${ }^{39}$ Claramente, a disputa judicial pela presidência norteamericana em Bush $v$. Gore não foi apenas um momento idiossincrático na história recente da política constitucional comparada. ${ }^{40}$

\section{Prerrogativas centrais do Executivo}

Outra área política que vem sendo crescentemente judicializada envolve as prerrogativas centrais de legislaturas e executivos no que se refere a relações exteriores, segurança nacional e política fiscal. A Suprema Corte do Canadá (SCC) não hesitou em rejeitar a doutrina da "questão política" (isto é, a não apreciação judicial de questões explicitamente políticas) após a adoção da Carta Canadense de Direitos e Liberdades, em 1982. ${ }^{41}$ No histórico julgamento Operation Dismantle v. A Rainha, por exemplo, a Corte decidiu por unanimidade que

quando um caso levanta a questão de se ações executivas ou legislativas violam a Constituição, a questão deve ser respondida pela Corte, não importando o caráter político da controvérsia (...) Disputas de natureza política ou de política exterior podem ser apropriadamente analisadas pelas cortes. ${ }^{42}$

Não surpreendentemente, a SCC se tornou um órgão decisório central para questões que vão do futuro de Quebec ao futuro da política de saúde pública no Canadá. ${ }^{43}$

A recém-criada Corte Constitucional russa seguiu a mesma direção no caso Chechênia, quando concordou em apreciar petições de vários membros da oposição na Duma, questionando a constitucionalidade de decretos presidenciais que ordenaram a invasão militar russa na Chechênia. ${ }^{44}$ Rejeitando a reivindicação chechena de independência e sustentando a constitucionalidade dos decretos do

\footnotetext{
39 Ver Bobb e Anor. UKPC 22 (Trin. \& Tobago), 2006. Disponível em: <www.bailii.org/uk/cases/ UKPC/2006/22.html>; Madagascar Court annuals election, BBC News Online, 17 mar. 2002. Disponível em: <http://news.bbc.co.uk/2/hi/africa/1935247.stm>.

${ }^{40}$ Ver Hasen (2004).

${ }^{41}$ Sobre a rejeição da doutrina da "questão política" nos EUA, ver Tushnet (2002).

${ }^{42}$ Operation Dismantle $v$. The Queen, 1985, 1 S.C.R. 441.

${ }^{43}$ Ver Chaoulli v. Que. (Att'y Gen.), 2005, 1 S.C.R. 791 (sustentando que os limites no fornecimento de saúde privada no Quebec violam a Carta de Direitos Humanos e Liberdades do Quebec). Três dos juízes também decidiram que os limites do fornecimento de saúde privada violam a seção 7 da Carta de Direitos e Liberdades. A decisão pode ter ramificações significantes na política de saúde do Canadá, e pode ser interpretada como uma abertura de caminho para o chamado sistema de saúde " $2 / 3$ ".

${ }^{44}$ Ver Russian Federation Constitutional Court's ruling regarding the legality of president Boris Yeltsin's degree to send troops to Chechnya, Official Kremlin International News Broadcast, 31 July 1995. Para uma análise em inglês, ver Pomeranz (1997).
} 
presidente Boris Yeltsin como intra vires, a maioria dos juízes da Corte declarou que a manutenção da integridade e unidade territorial da Rússia seria "uma regra inabalável que exclui a possibilidade de uma secessão unilateral armada em qualquer estado federativo". ${ }^{45}$ Em 2004, a Suprema Corte israelense decidiu sobre a constitucionalidade e a compatibilidade com o direito internacional da barreira da Cisjordânia - uma polêmica rede de cercas e muros que separam Israel do território palestino. ${ }^{46}$

Uma manifestação ligeiramente diferente, mas igualmente significativa, de intervenção judicial na esfera política - desta vez, no contexto de políticas fiscais e de bem-estar social - pode ser encontrada nas Decisões do Pacote Econômico de Austeridade (os chamados "Casos Bokros"), da Corte Constitucional húngara. ${ }^{47}$ Neste caso, a Corte se apoiou nos conceitos de proteção de expectativas e certeza jurídica para anular cerca de 26 regras de um abrangente plano econômico de emergência adotado pelo governo. O plano tinha como medida principal um corte substancial nos gastos públicos com benefícios sociais, pagamento de aposentadorias, educação e saúde, com a finalidade de reduzir o enorme déficit orçamentário e a dívida externa da Hungria. ${ }^{48}$ Outra manifestação igualmente significativa da judicialização de problemas macroeconômicos controvertidos é a decisão da Suprema Corte da Argentina, de outubro de 2004 (o chamado "Caso Corralito"), sobre a constitucionalidade do plano de "pesificação" proposto pelo governo (conversão total da economia argentina em pesos, com taxa de câmbio fixa em relação ao dólar norte-americano), e a correspondente desvalorização e congelamento de poupanças atreladas ao dólar - uma consequência da grande crise econômica argentina de $2001 .^{49}$

Entretanto, se por um lado tem havido uma crescente penetração judicial nas prerrogativas de legislaturas e executivos a respeito de relações exteriores, segurança nacional e política fiscal, os tribunais têm no geral permanecido passivos no que se refere a políticas sociais e de redistribuição de riqueza e recursos. Com pouquíssimas exceções (principalmente na África do Sul e na Índia), os tribunais têm sido tímidos quando se trata de promover noções progressistas de justiça distributiva em áreas como distribuição de renda, erradicação da pobreza e direitos

\footnotetext{
${ }^{45}$ Russian Court: Chechen War Legal, United Press Int'l, 31 jul. 1995. Disponível em: Lexis UPI database; ver também Gaeta, Paola. The armed conflict in Chechnya before the Russian Constitutional Court, 7 Eur. J. Int'1 L. 563, 1996.

${ }^{46}$ HCJ 2056/04 Beit Sourik Vill. Council v. Gov't of Isr. 2005. IsrSC, v. 58, n. 5, p. 807. Isr. L. Rev., n. 83, 2005.

${ }^{47}$ Uma tradução para o inglês desse caso está disponível em Sólyom, László e Brunner, Georg (2000).

${ }^{48}$ Idem.

${ }^{49}$ Corte Suprema de Justicia (CSJN), 26 out. 2004. Bustos, Alberto Roque et al. $v$. Estado Nacional et al. Disponível em: <www.csjn.gov.ar>.
} 
relacionados à subsistência (educação básica, saúde e moradia), cuja implementação requer maior intervenção estatal e mudanças nas prioridades dos gastos públi$\cos ^{50}$ Assim, pode-se dizer que a judicialização de questões envolvendo poderes fundamentais do Executivo não tem sido exatamente uma bênção para keynesianos e progressistas.

\section{Corroboração de mudanças de regime}

Outra área de crescente envolvimentojudicial em megapolítica éa (in)validação de mudanças de regime. O exemplo mais óbvio é a saga da "certificação constitucional" na África do Sul: foi a primeira vez que uma corte constitucional se recusou a aceitar um texto constitucional elaborado por um órgão constituinte representativo. ${ }^{51}$ Outras manifestações recentes desse tipo de judicialização incluem a raramente mencionada, mas impressionante, restauração da Constituição de Fiji de 1997 pela Corte de Apelações de Fiji em Fiji v. Prasad, em 2001 - a primeira vez na história do constitucionalismo moderno em que um tribunal restaurou uma constituição e o sistema de governo democrático que o criou,; 5 a decisão histórica da Suprema Corte do Nepal, de fevereiro de 2006, que declarou inconstitucional a controversa Comissão Real para o Controle da Corrupção (CRCC), estabelecida após o golpe de Estado de 2005, abrindo caminho para a libertação do primeiro-ministro deposto, Bahadur Deuba, detido desde julho de 2005 por ordem da CRCC; 53 e a rejeição, pela Corte Constitucional da Coreia do Sul, do impeachment do presidente Roh Moo-hyun realizado pela Assembleia Nacional do país, em 2004 - a primeira vez na história do constitucionalismo moderno em que um presidente foi reconduzido ao cargo por um órgão judicial após um órgão legislativo ter determinado o seu impeachment. ${ }^{54}$

Vale destacar também o endosso, pela Suprema Corte do Paquistão, da legitimidade do golpe de Estado militar de 1999. Alegando corrupção generalizada e grave má administração econômica por parte do governo, o general Pervez Musharraf tomou o poder do primeiro-ministro Nawaz Sharif em um golpe de Estado militar, em 12 de outubro de 1999. Musharraf se autodeclarou o novo che-

\footnotetext{
${ }^{50}$ Hirschl, 2005.

${ }^{51}$ Ver Certification of the amended text of the Constitution of the Republic of S. Afr. 1997 (2) SA 97 (CC); Certification of the Constitution of the Republic of S. Afr. 1996 (4) SA 744 (CC).

${ }^{52}$ Ver Republic of Fiji Islands v. Prasad,2001, 1 LRC 665 (HC), 20022 LRC 743 (CA).

${ }^{53}$ Ver Nepal corruption panel outlawed, BBC News, 13 Feb. 2006. Disponível em: <http://news.bbc.co.uk/2/ hi/south_asia/4708472.stm>.

${ }^{54}$ Lee, Youngjae. Law, politics, and impeachment: the impeachment of Roh Moohyun from a comparative constitutional perspective, 2005.
} 
fe do Executivo, deteve o primeiro ministro Sharif e diversos aliados políticos e promulgou uma Proclamação de Emergência, suspendendo todas as operações do governo Sharif, da Assembleia Nacional e do Senado. Em resposta, ativistas políticos contrários ao golpe militar encaminharam uma petição à Suprema Corte em meados de novembro de 1999, contestando a legalidade da derrubada do governo Sharif e da Proclamação de Emergência e exigindo a libertação de Nawaz Sharif e a restauração de seu governo eleito. Em uma decisão largamente divulgada, anunciada em maio de 2000, a Suprema Corte do Paquistão se baseou na doutrina do "estado de necessidade" para validar, por unanimidade, o golpe de outubro de 1999, considerando ter sido o mesmo necessário para livrar o país do caos e da falência..$^{55}$ A Corte sustentou que:

(em) 12 de outubro de 1999, surgiu uma situação para a qual a Constituição não fornecia solução e a intervenção das Forças Armadas através de uma medida extraconstitucional se tornou inevitável, o que é aqui validado com base na doutrina do estado de necessidade e no princípio do salus populi suprema lex (...) Material suficiente foi produzido para corroborar (...) e apoiar a intervenção das Forças Armadas através de medida extraconstitucional. ${ }^{56}$

Entretanto, o presidente da Corte, Irshad Hasan Khan, complementou que "um prolongado envolvimento do Exército em assuntos civis corre o grave risco de politizá-lo, o que não seria do interesse nacional e, portanto, o governo civil deve ser restaurado o mais breve possível no país". ${ }^{57}$ Nesse sentido, a Corte deu ao general Musharraf três anos para implementar reformas econômicas e políticas e restaurar a democracia. ${ }^{58}$ A Corte anunciou que o general Musharraf (presidente Musharraf, a partir de junho de 2001) deveria escolher uma data até 90 dias antes do final do período de três anos para a realização de eleições para a Assembleia Nacional, para as assembleias provinciais e para o Senado.$^{59} \mathrm{O}$ Paquistão é um país em um limbo político quase constante. Mas uma coisa é clara: a batalha judicial sobre a legitimidade política do regime de Musharraf realçou o papel político central da Suprema Corte no Paquistão nos dias de hoje. ${ }^{60}$

\footnotetext{
${ }^{55}$ Zafar Ali Shah v. Pervez Musharraf, Chief Executive of Pak., P.L.D. 2000 S.C. 869.

${ }^{56}$ Idem, p. 1219.

${ }^{57}$ Idem.

${ }^{58}$ Idem, p. 1219-1223.

${ }^{59}$ Idem, p. 1223.

${ }^{60}$ Desde 1990, o Paquistão passou por cinco mudanças de regime e a Corte Suprema do Paquistão exerceu um papel fundamental em cada uma dessas transições radicais. Ver Zafar Ali Shah $v$. Pervez Musharraf, Chief Executive of Pak., P.L.D. 2000 S.C. 869; Benazir Bhutto v. President of Pak., P.L.D. 1998 S.C. 388; Muhammad Nawaz Sharif v. President of Pak., P.L.D. 1993 S.C. 473; Begum Nusrat Bhutto $v$. Chief of Army Staff, P.L.D. 1977 S.C. 657.
} 


\section{Justiça transicional}

Uma quarta área emergente da megapolítica que, nas últimas décadas, tem sido judicializada de forma rápida e em grau talvez excessivo é a da justiça transicional ou restaurativa. A transferência cada vez mais comum, da esfera política para os tribunais, de dilemas morais e políticos fundamentais ligados a injustiças extremas e atrocidades em massa cometidas contra grupos e indivíduos historicamente desfavorecidos apresenta algumas subcategorias, cada uma refletindo diferentes noções de justiça restaurativa. Existem muitos exemplos recentes de judicialização da justiça restaurativa. Lembremos da era pós-Apartheid na África do Sul: a fórmula anistia-em-troca-de-confissão obteve luz verde por parte da Corte Constitucional sul-africana no caso Azanian Peoples' Organization ("Azapo") v. Presidente da República da África do Sul (1996), sustentando o estabelecimento da Comissão de Verdade e Reconciliação, de caráter quase judicial. ${ }^{61} \mathrm{Ou}$ consideremos o importante papel cumprido pelas recém-criadas cortes constitucionais na Europa pós-comunista no confronto com o passado por meio de julgamentos de ex-funcionários públicos acusados de atos que, hoje, são considerados violações de direitos humanos da era comunista. ${ }^{62}$ Da mesma forma, ocorreu uma judicialização generalizada da justiça restaurativa em países latino-americanos pós-autoritários (consideremos, por exemplo, a batalha judicial sobre o destino de Augusto Pinochet, ex-ditador do Chile). Outro exemplo seria a grande judicialização das disputas sobre o status de povos indígenas nas chamadas "colônias de povoamento", como Austrália, Canadá e Nova Zelândia.

A judicialização da justiça restaurativa também é evidente no nível transnacional. Mais uma vez, os exemplos são muitos. O Tribunal Penal Internacional (TPI) (ratificado por 90 países até 2006) foi estabelecido em 1998 como um órgão judicial internacional permanente com jurisdição potencialmente universal sobre genocídio, crimes contra a humanidade, crimes de guerra etc. ${ }^{63} \mathrm{O}$ Tribunal Penal Internacional para a ex-Iugoslávia na Haia foi estabelecido em $1993 .{ }^{64}$ Nele, Slobodan Milosevic foi levado a julgamento. ${ }^{65}$ Outro exemplo é o Tribunal Penal Internacional para Ruanda em Arusha, na Tanzânia, estabelecido em 1995. Também estão incluídas nessa categoria as "cortes híbridas" recém-criadas no Camboja, Timor Leste, Iraque, Kosovo e Serra Leoa. Todas elas são tribunais internacionais

\footnotetext{
${ }^{61}$ Azanian Peoples' Organization ("Azapo") v. President of the Republic of S. Afr. 1996 (4) SA 672 (CC).

${ }^{62}$ Ver Schwartz (2000) e Quint (1999).

${ }^{63}$ Ver Schabas (2004).

${ }^{64}$ Ver Kerr (2004).

${ }^{65}$ Idem.
} 
de justiça restaurativa que trabalham sob as regras dos sistemas legais domésticos e aplicam uma combinação de direito internacional e doméstico, substantivo e processual.

\section{Definindo a nação através dos tribunais}

Todas essas áreas de megapolítica judicializada, porém, são mera introdução para o que pode ser considerado a mais clara manifestação da judicialização generalizada de controvérsias políticas fundamentais: o crescente recurso aos tribunais para contemplarem a própria definição, ou raison d'être, da comunidade. Consideremos, por exemplo, o envolvimento sem precedentes do Judiciário canadense na questão do status bilíngue do país e do futuro político de Quebec e da federação canadense, incluindo a histórica decisão da Suprema Corte canadense na Consulta sobre a Secessão de Quebec - a primeira vez em que um país democrático testou antecipadamente os termos jurídicos de sua própria dissolução. Da mesma forma, a Corte Constitucional Federal alemã exerceu papel-chave na criação da Alemanha unificada, como ficou claro, por exemplo, no caso Maastricht, no qual a Corte se baseou em provisões da Lei Fundamental alemã para determinar o status da Alemanha pós-unificação vis-à-vis a emergente comunidade supranacional européia. Existem muitos exemplos desse fenômeno: o papel central que a Corte Constitucional turca exerceu na preservação da natureza estritamente secular do sistema político turco, reprimindo continuamente forças e partidos políticos antissecularistas; a importante jurisprudência da Suprema Corte da Índia sobre o status das leis pessoais religiosas mulçumana e hindu; ${ }^{66}$ o papel crucial dos tribunais em diversas teocracias constitucionais, como Egito e Malásia, na determinação da natureza da vida pública nesses estados modernos formalmente governados por princípios da Shari'a islâmica; ${ }^{67}$ a transferência generalizada da profunda divisão entre o religioso e o secular, na sociedade israelense, para o Judiciário, através da judicialização da questão "quem é judeu?" e o correspondente envolvimento da Suprema Corte de Israel na interpretação da definição fundamental de Israel como um "Estado democrático e judaico." No nível supranacional, podemos pensar no papel-chave da Corte Europeia de Justiça na implementação e aceleração do processo de integração europeu - papel que está destinado a crescer com a expansão da fronteira leste da UE, em 2004, e com a possibilidade de uma Constituição europeia.

\footnotetext{
${ }^{66}$ Ver Mohammed Ahmed Khan v. Shah Bano Begum, A.I.R. 1985 S.C. 945 (Índia).

${ }^{67}$ Para uma discussão sobre o papel das cortes no Egito, ver Hirschl, Ran. Constitutional courts vs. Religious fundamentalism: three middle eastern tales. Tex. L. Rev. p. 1819, 1829-1833, 2004. Para Malásia, ver Peletz, Michael G. Islamic modern: religious courts and cultural politics in Malaysia, 2002.
} 
Para melhor apreender a natureza puramente política desses julgamentos, é necessária uma discussão mais detalhada de alguns casos ilustrativos. Comecemos pela Europa. No histórico caso Maastricht, a Corte Constitucional Federal alemã foi provocada a definir, com base na Lei Fundamental alemã, o status da Alemanha pós-unificação vis-à-vis a comunidade supranacional europeia emergente. ${ }^{68} \mathrm{O}$ art. 38 da Lei Fundamental dá aos cidadãos alemães o direito de votar nos seus representantes parlamentares. ${ }^{69} \mathrm{O}$ art. 20 (2) da Lei Fundamental dá aos cidadãos-eleitores o direito de participar no exercício da autoridade estatal por meio de seus deputados. ${ }^{70}$ Os peticionários argumentaram que a criação da União Europeia, através do Tratado de Maastricht de 1992, implicava uma transferência de autoridade para tomada de decisões políticas do âmbito nacional para o supranacional, colocando parte considerável dessa autoridade além do âmbito de ação dos legisladores nacionais. Mais especificamente, a transferência de autoridade para a União Europeia constituiria uma renúncia de poder por parte do Bundestag, infringindo, assim, o direito dos cidadãos alemães de influenciar o exercício do poder estatal através do voto. E, assim, mais uma vez, um tribunal nacional foi chamado para clarificar e resolver uma controvérsia política fundamental - dessa vez, as inter-relações entre o eleitor alemão, o Bundestag e a comunidade supranacional europeia emergente.

Em sua decisão, o Tribunal Constitucional Federal alemão analisou em detalhes as razões por trás da criação da comunidade supranacional europeia e estipulou as condições necessárias para a obtenção de legitimidade democrática no âmbito supranacional. $\mathrm{O}$ tribunal seguiu definindo a competência legislativa dos Estados-membros e parlamentos nacionais em relação à UE, e declarou que o Bundestag deveria reter para si funções e poderes de importância substancial. Mais ainda, o tribunal declarou que "o art. 38 da Constituição é violado quando um ato abre o sistema jurídico alemão para a aplicação do direito das comunidades supranacionais europeias (se este ato) não estabelece com certeza suficiente quais poderes são transferidos e como eles serão integrados". ${ }^{71} \mathrm{O}$ tribunal também sustentou que os princípios fundamentais de participação e representação política não impediriam a participação alemã na UE, desde que a transferência de poder para esses órgãos "permanecesse enraizada no direito dos cidadãos alemães de votar e, assim, participar no processo nacional de elaboração legislativa". Em outras palavras, o tribunal não hesitou

\footnotetext{
${ }^{68}$ Uma versão resumida da decisão aparece em Kommers (1997:182-186 e 187-193).

${ }^{69}$ Grundgesetz (Constituição) art. 38 (F.R.G.). Disponível em: <www.bundestag.de/htdocs_e/info/ germanbasiclaw.pdf $>$.

${ }_{70}^{7 d e m, ~ a r t . ~} 20$.

${ }^{71}$ Ver Kommers (1997).
} 
em lidar com uma questão política explícita. Ao contrário, sustentou a constitucionalidade do Tratado de Maastricht - o documento constitutivo da noção de "união cada vez mais próxima" - , colocando o tratado sob o escrutínio da Lei Fundamental e seus princípios.

Outro revelador exemplo de articulação judicial dos valores centrais da nação pode ser encontrado no papel exercido pela Suprema Corte Constitucional do Egito quando lidou com a crucial questão do status das regras da Shari'a - provavelmente o problema de identidade coletiva mais controverso e fundamental da comunidade egípcia. Desde o estabelecimento, em 1979, do controle de constitucionalidade no Egito, e da emenda constitucional de 1980, que tornou a Shari'a islâmica a principal fonte legislativa do país, ${ }^{72}$ a Corte vem sendo cada vez mais chamada a determinar a constitucionalidade de atos legislativos e administrativos com base em sua compatibilidade com os princípios da Shari'a. ${ }^{73}$ "A questão diante da Corte em todos esses casos tem sido a de quais princípios da Shari'a possuem autoridade determinante e absoluta". ${ }^{74}$

Para abordar essa questão de forma moderada, a Corte desenvolveu uma complexa matriz interpretativa de diretivas religiosas - a primeira desenvolvida por um tribunal não religioso. Afastou-se de tradições antigas das escolas figh (jurisprudência islâmica ou o conhecimento/ciência acumulados sobre a Shari'a) e desenvolveu um novo quadro para interpretar a Shari'a. ${ }^{75}$ Mais especificamente, a Corte desenvolveu uma abordagem flexível e modernista para a interpretação da Shari'a, distinguindo entre "princípios inalteráveis e universalmente vinculantes" e "aplicações maleáveis dos princípios". ${ }^{76}$ Uma legislação que contrarie um princípio estrito, inalterável, é declarada inconstitucional e nula mas, por outro lado, a ijtihad (interpretação externa) é permitida em casos de lacuna, ou quando as regras pertinentes são vagas ou têm finalidades abertas. ${ }^{77}$ Mais ainda, foi concedida ao governo uma grande margem de discricionariedade em questões de políticas públicas nas quais a Shari'a não fornece respostas claras ou unívocas, desde que o resultado da elaboração normativa não contrarie o espírito geral da Shari'a. ${ }^{78}$ Essa abordagem interpretativa marcou uma verdadeira mudança de paradigma na legitimação de políticas de governo baseadas em uma interpretação (ijtihad) moderada e razoavelmente liberal da Shari'a.

\footnotetext{
${ }^{72}$ Constituição do Egito, cap. I, art. 2. Disponível em: <www.egypt.gov.eg/english/laws/constitution/ index.asp>.

${ }^{73}$ Ver Gabr (1996).

${ }^{74}$ Hirschl (2004:1.823).

${ }^{75}$ Ver Brown (1999:491).

${ }^{76}$ Idem, p. 496.

${ }^{77}$ Idem.

${ }^{78}$ Idem, p. 497.
} 
A Corte aplicou tal abordagem no caso Riba, ${ }^{79}$ no histórico caso $\mathrm{Niq}^{\prime} \mathrm{ab}^{80}$ e no pioneiro caso Khul', em que a Corte sustentou a constitucionalidade da Lei de Status Pessoal, de 2000, mantendo os dispositivos que estabelecem o direito de uma mulher mulçumana invocar o $\mathrm{khul}^{\prime}$ - divórcio sob qualquer justificativa e sem o consentimento do marido - desde que os presentes de joias (shabka) e pagamentos de dote (mahr) do noivo sejam devolvidos e que se renuncie a certos direitos patrimoniais. ${ }^{81}$ Ao anunciar a decisão da Corte, o ministro Maher El-Bahri confirmou que a incorporação do khul' na lei egípcia sobre status pessoal não viola a Shari'a ou o art. $2^{\circ}$ da Constituição, já que existem versos claros no Alcorão e figh correspondentes sustentando o procedimento do khul'.

Neste e em outros julgamentos fundamentais a respeito do escopo da Shari'a na vida pública do Egito, a Corte realizou uma interpretação substantiva autônoma do Alcorão e de evidências disponíveis na Suna. De fato, a Corte estabeleceu sua própria interpretação da ijtihad, apesar da existência de opiniões contraditórias na jurisprudência islâmica, a figh, e seus métodos tradicionais. Dessa forma, a Suprema Corte Constitucional do Egito se posicionou como intérprete de fato de normas religiosas - e como um fórum central para lidar com o dilema da teocracia constitucional do Egito.

Talvez em nenhum outro lugar do mundo a judicialização da megapolítica esteja mais evidente do que na vizinha Israel - provavelmente, o país mais próximo de uma completa juristocracia em todo o planeta. Toda semana, a Suprema Corte de Israel (SCI) anuncia uma decisão significativa, amplamente divulgada pela mídia e assistida de perto pelo sistema político. Os exemplos mais claros do envolvimento profundo da SCI em questões formativas de identidade coletiva são os recentes julgamentos sobre a questão "quem é judeu" - possivelmente a questão mais carregada de implicações sobre identidade coletiva na Israel de hoje. A corrente ortodoxa do judaísmo é a única formalmente reconhecida pelo Estado. Este status exclusivo permitiu que a comunidade ortodoxa estabelecesse um quase

\footnotetext{
${ }^{79} \mathrm{O}$ caso Presidente da al-Azhar Univ. v. Presidente da República (o caso Riba), no 20 do primeiro ano judicial (4 de maio de 1985), é discutido em Vogel, Frank E. Conformity with Islamic Shari'a and constitutionality under article 2: some issues of theory, practice and comparison. In: Brown (1999:525-534).

${ }^{80}$ Wassel $v$. Ministro da Educação (o caso Niq'ab), no 8 do ano judicial 17 (18 de maio de 1996). Traduzido em Cotran e Mallat (1996:178-180). Sustenta a constitucionalidade de um decreto governamental que permitia que as pessoas responsáveis por alunas abaixo do nível universitário requisitassem que elas cobrissem seus cabelos, desde que não fosse exigido encobrir os rostos (que elas usassem uma hijab - cobertura de cabeça - e não uma nigab - máscara ou cobertura total de cabeça).

${ }^{81}$ A nova lei permitiu esse divórcio por ordem judicial (sem o consentimento do marido) depois que um processo de mediação e reconciliação obrigatórias falhasse. Essas novas provisões efetivamente tornaram ilegais práticas abusivas de homens que se divorciavam de suas esposas apenas dizendo "Eu me divorcio de você" (talaq al-bid'a) três vezes, contornando qualquer esforço para mediar ou reconciliar os cônjuges (talaq al-ghyabi). Ver Khul' law passes major test, Al-Ahram Weekly Online, 19-25 dez. 2002. Disponível em: <http://weekly.ahram.org.eg/2002/617/eg11.htm>.
} 
monopólio na prestação de serviços religiosos públicos e que impusesse critérios rígidos no processo de determinação de "quem é judeu". Essa pergunta tem implicações simbólicas e práticas cruciais, na medida em que, de acordo com a Lei do Retorno, judeus que imigram para Israel recebem uma variedade de benefícios, incluindo o direito imediato à cidadania plena. ${ }^{82}$ Imigrantes não judeus não recebem tais benefícios. Já que ser judeu é suficiente para obter cidadania, a autodefinição do Estado como um Estado judaico é inseparável da definição de "quem é judeu". Não surpreendentemente, a batalha sobre a conversão ao judaísmo tem sido assistida de perto por judeus dentro e fora de Israel.

Assim como em outros assuntos políticos polêmicos em Israel, a incompetência ou a falta de vontade do sistema político em lidar com o problema (somadas às incrivelmente generosas regras de acesso à SCI) levaram a questão "quem é judeu" à SCI. Em 1989, quando a iniciativa da revolução constitucional estava em seus estágios iniciais, a SCI decidiu que, para fins de imigração, qualquer pessoa convertida ao judaísmo fora de Israel, independentemente de a conversão ter sido feita por instituição religiosa ortodoxa, conservadora ou reformista, teria acesso automático a todos os direitos de um oleh (imigrante judeu), nos termos da Lei do Retorno e da Lei de Cidadania. ${ }^{83}$ Em 1995, a SCI foi mais uma vez arrastada para as turvas águas da política de identidades. Dessa vez, o problema era se uma pessoa não judia que se submetera a uma conversão não ortodoxa em Israel teria direito automático à cidadania, com base no direito de retorno. A SCI evitou dar uma resposta clara ao mesmo tempo que reafirmou explicitamente seu julgamento anterior, que validara conversões não ortodoxas feitas fora do país. ${ }^{84}$

Após tal decisão, um número crescente de não judeus residindo em Israel (sobretudo trabalhadores estrangeiros e imigrantes não judeus da antiga União Soviética) foi ao exterior para obter conversão não ortodoxa com o intuito de reivindicar os benefícios concedidos pelo Estado aos recém-chegados reconhecidos como judeus. Em resposta, o ministro do Interior (então controlado pelo partido ultraortodoxo Shas) renovou sua recusa em reconhecer conversões reformistas e conservadoras feitas no exterior. Em novembro de 1999, a SCI revisitou o assunto, declarando que, se as partes envolvidas falhassem em chegar a um acordo até abril de 2000, um painel expandido de 11 juízes abordaria o problema da conversão. Nenhum compromisso foi obtido no prazo e a SCI concluiu sua deliberação no final daquele ano. A judicialização da questão sobre a conversão culminou no

\footnotetext{
${ }^{82}$ A Lei do Retorno, 1970, S.H. 586 (Isr.). Disponível em: <www.knesset.gov.il/laws/special/eng/return. $\mathrm{htm}>$. Concede a judeus o direito de "retorno" a Israel para adquirir cidadania, mesmo que não tenham tido qualquer contato prévio com o Estado.

${ }^{83}$ HCJ 264/87 Sepharadi Torah Guardians-Shas Movement v. Population Registrar. IsrS, v. 43, n. 2, p. 723-731, 1989.

${ }^{84}$ HCJ 1031/93. Pessaro (Goldstein) et al. v. Minister of the Interior. IsrSC, v. 49, n. 4, p. 661, 1995.
} 
início de 2002 com a histórica decisão da SCI (por nove votos a dois) de reconhecer conversões não ortodoxas realizadas no exterior. ${ }^{85} \mathrm{~A}$ SCI ordenou que o ministro do Interior registrasse como judeus os cidadãos israelenses que haviam sido convertidos pelos movimentos conservador e reformista no exterior. ${ }^{86} \mathrm{Na}$ justificativa, a SCI se baseou em uma antiga convenção segundo a qual o censo populacional do ministério deve se abster de questionar cidadãos israelenses acerca dos detalhes de suas crenças. ${ }^{87}$

Em março de 2005, a SCI proferiu outro julgamento histórico sobre uma questão que perpassa o coração da identidade coletiva do Estado judeu. ${ }^{88}$ Um grupo de trabalhadores estrangeiros residentes em Israel havia estudado para conversões reformistas e conservadoras no país, mas teve as cerimônias realizadas no exterior, em uma tentativa de "driblar" o reconhecimento exclusivo para conversões ortodoxas em Israel. O ministro do Interior objetou contra essas conversões bypass (conhecidas em Israel como "conversões saltadoras", já que requerem um pequeno "pulo" em uma jurisdição estrangeira), argumentando que a Lei do Retorno não se aplica a estrangeiros já residentes em Israel, e que conversões bypass não contam validamente como conversões no exterior. Em uma decisão por sete votos a quatro, a SCI concordou com os peticionários e reconheceu conversões não ortodoxas do tipo bypass feitas de jure no exterior, mas de facto em Israel. A SCI sustentou que uma pessoa que foi para Israel como não judeu e, durante um período de residência legal, converteu-se em uma comunidade judaica reconhecida no exterior deve ser considerada judia. O presidente da SCI, Aharon Barak, escreveu:

A nação judaica é uma só... Ela está dispersa pelo mundo, em comunidades. Quem se converteu ao judaísmo em uma dessas comunidades no exterior aderiu à nação judaica, e deve ser visto como um "judeu" de acordo com a Lei do Retorno. Isto pode encorajar a imigração para Israel e manter a unidade da nação judaica na Diáspora e em Israel. ${ }^{89}$

Lembremos que isso deveria ser uma decisão judicial, não um discurso ou manifesto político..$^{90}$

\footnotetext{
${ }^{85}$ HCJ 5070/95 Working and Volunteering Women Movement $v$. Minister of Interior. IsrSC,v. 56, n. 2, p. 721, 2002.

${ }^{86}$ Idem.

${ }^{87}$ Idem.

${ }^{88}$ Yoaz, Yuval. Court recognizes non-orthodox overseas conversion of israeli residents. Haaretz, 4 jan. 2005. Disponível em: <www.haaretz.com/hasen/pages/ShArt.jhtml?itemNo=559673\&contrassID=1\&sub ContrassID $=1 \&$ sbSubContrassID $=0 \&$ list $\mathrm{Src}=\mathrm{Y}>$.

${ }^{89}$ Idem.

${ }^{90}$ Compare esta clara manifestação da judicialização de questões fundamentais sobre identidade coletiva (a terceira face da judicialização) com aspectos menos relevantes das mesmas questões de identida-
} 
Outro exemplo claro de judicialização da megapolítica pode ser visto no envolvimento sem precedentes da Suprema Corte do Canadá com o status bilíngue do país e com o futuro político de Quebec e da federação canadense, mais notavelmente na histórica decisão da Corte na Consulta sobre a Secessão de Quebec. ${ }^{91} \mathrm{O}$ que torna essa decisão tão única não é apenas o fato de ter sido a primeira vez que um país democrático testou antecipadamente os termos de sua própria dissolução, mas também a liberdade e a autoridade com que a Corte articulou os pilares fundamentais da comunidade canadense - e de uma forma que nenhum outro órgão estatal jamais havia feito. Em setembro de 1996, após uma apertada derrota de 50,6\% a 49,4\% do movimento de secessão de Quebec no referendo de 1995, o governo federal canadense se baseou no procedimento de consulta para solicitar à Suprema Corte do Canadá que determinasse se uma hipotética declaração de secessão unilateral do governo de Quebec seria constitucional. Na consulta submetida por Ottawa à Suprema Corte, três questões foram levantadas:

(1) De acordo com a Constituição do Canadá, podem a Assembleia Nacional, a legislatura ou o governo de Quebec efetuar a separação de Quebec do Canadá de forma unilateral? (2) O direito internacional dá à Assembleia Nacional, à legislatura ou ao governo de Quebec o direito de efetuar a separação de Quebec do Canadá de forma unilateral? Em outras palavras, existe no direito internacional um direito à autodeterminação aplicável a Quebec? (3) Se existe um conflito entre o direito internacional e a Constituição canadense sobre a secessão de Quebec, o que deve prevalecer? ${ }^{92}$

Em uma decisão amplamente divulgada, em agosto de 1998, a SCC sustentou por unanimidade que a secessão unilateral seria um ato inconstitucional em face tanto do direito doméstico, quanto do internacional, e que o voto majoritário em

\footnotetext{
de (a segunda face da judicialização): Fred é convertido ao judaísmo por um rabino ortodoxo que, por estar cansado naquele dia, comete um ou dois erros procedimentais durante o processo. Uma semana depois, o rabino percebe seu erro e insiste que Fred passe pelo procedimento correto. Fred diz não e o debate chega às cortes. Apesar de o debate judicial envolver aspectos da pergunta sobre "quem é judeu", eles são incidentais para a questão procedimental central em jogo. Agradeço a Mark Graber por clarificar esse ponto.

${ }_{91}$ Reference re secession of Que., 19982 S.C.R. 217. Ver também A.G. (Que.) v. Que. Protestant Sch. Bds., 1984, 2 S.C.R. 66. Afirma a inconstitucionalidade de provisos sobre instrução em inglês. Reference re objection to resolution to amend the Constitution, 1982, 2 S.C.R. 793. Sustenta que Quebec não tinha poder para vetar emendas constitucionais, afetando a competência legislativa de Quebec. Re resolution to amend the Constitution, 1981, 1 S.C.R. 753. Sustenta que, de um ponto de vista puramente legal, as Casas do Parlamento do Canadá poderiam requisitar unilateralmente emendas à Constituição do Canadá, apesar de existir convenção constitucional exigindo consentimento substantivo das províncias.

${ }^{92}$ Reference re Secession of Que., 1998, 2 S.C.R., p. 228.
} 
Quebec não seria suficiente para permitir a essa província se separar legalmente do resto do Canadá. ${ }^{93}$ Entretanto, a Corte também notou que, se a secessão fosse aprovada por uma clara maioria das pessoas em Quebec, votando em um referendo sobre uma pergunta clara, as partes deveriam negociar de boa-fé os termos da separação subsequente. ${ }^{94}$ Quanto à questão da possibilidade de secessão unilateral no direito canadense, a Corte deu respostas que não desagradaram completamente nem aos federalistas, nem aos separatistas.

Em termos estritamente legais, a Corte decidiu que a secessão do Quebec envolveria uma mudança significativa na Constituição do Canadá, o que requereria uma emenda constitucional, que por sua vez requereria negociações entre todas as partes envolvidas. ${ }^{95}$ No nível normativo, a Corte declarou que a Constituição canadense é baseada em quatro princípios fundamentais igualmente importantes: (1) federalismo, (2) democracia, (3) constitucionalismo e estado de direito, e (4) a proteção das minorias. ${ }^{96}$ Nenhum desses princípios prevalece sobre os outros. ${ }^{97}$ Assim, mesmo uma votação majoritária (aderência estrita ao princípio democrático e à regra da maioria) não seria suficiente para permitir que Quebec se separasse unilateralmente. ${ }^{98}$ Porém, a Corte declarou que, se uma maioria clara dos quebecois votasse "sim" para uma questão inequívoca sobre a separação de Quebec, isto "conferiria legitimidade aos esforços do governo de Quebec para iniciar o processo de emenda constitucional para se separar através de meios constitucionais". ${ }^{99}$ Esta "maioria clara em uma pergunta clara" obrigaria o governo federal a negociar de boa-fé com Quebec para chegar a um acordo quanto aos termos da separação. ${ }^{100}$

Em relação ao direito internacional, a resposta da Corte foi muito mais curta e objetiva: foi decidido que, apesar de o direito à autodeterminação dos povos existir no direito internacional, ele não se aplicaria a Quebec. ${ }^{101}$ Evitando a questão controversa de se a população de Quebec, ou parte dela, constitui um "povo" no sentido corrente do direito internacional, a Corte sustentou que o direito à secessão unilateral não se aplica a Quebec. Aos quebecois não é negada a capacidade de buscar seu "desenvolvimento político, econômico, social e cultural dentro do quadro de um Estado existente", nem constituem um povo colonial e oprimido. ${ }^{102}$

\footnotetext{
${ }^{93}$ Reference re Secession of Que., p. 259-260.

${ }^{94}$ Idem, p. 293.

${ }^{95}$ Idem.

${ }^{96}$ Idem, p. 247-263.

${ }^{97}$ Idem, p. 248.

${ }^{98}$ Idem, p. 259-261.

${ }^{99}$ Idem, p. 265.

${ }^{100}$ Idem, p. 271.

${ }^{101}$ Idem, p. 277.

${ }^{102}$ Idem, p. 282.
} 
O governo de Quebec respondeu à decisão promulgando uma lei declarando que quando uma maioria de " $50 \%$ mais um" dos quebecois apoiasse em um referendo provincial a ideia de secessão, estaria satisfeito o requerimento de "maioria clara" estabelecido pela decisão da Corte. O governo federal, por sua vez, respondeu no final de 1999 propondo a "Lei da Clareza", formalmente confirmada pelo Parlamento no verão de $2000 .{ }^{103}$ Resumidamente, a lei declara que apenas "uma maioria clara em uma pergunta clara" teria o poder de obrigar o governo federal a negociar os termos de separação com Quebec; e ainda que, dada a natureza da questão, o termo "maioria clara" deveria significar mais do que " $50 \%$ mais um"; e que, em qualquer caso, o governo federal se reserva o direito de determinar se a pergunta colocada pelo governo de Quebec em um futuro referendo obedece ao critério da "pergunta clara".

Sem conhecer o contexto político destes eventos e decisões, o leitor não canadense pode achar supreendente essa cadeia de eventos judiciais definindo o status de Quebec. Uma coisa, porém, é inquestionável: nos últimos 25 anos, a SCC se tornou um dos mais importantes fóruns públicos para lidar com a altamente controversa questão do status de Quebec e sua futura relação com o resto do Canadá. Graças ao novo cenário constitucional estabelecido pelo Ato Constitucional de 1982 e à disposição da SCC em exercer um papel central na saga de Quebec, as partes envolvidas (principalmente os federalistas) foram capazes de gradualmente transferir a questão de Quebec da esfera política para a esfera jurídica.

Em suma, em numerosos países ao redor do mundo tem havido uma crescente deferência legislativa ao Judiciário, uma crescente intrusão do Judiciário em prerrogativas de legislaturas e executivos, e uma correspondente aceleração do processo por meio do qual agendas políticas têm sido judicializadas. Juntos, tais desenvolvimentos contribuíram para a crescente confiança em meios judiciais para clarificar e resolver controvérsias morais fundamentais e questões políticas altamente controversas, transformando tribunais superiores nacionais em importantes órgãos de decisões políticas. A onda de ativismo judicial que inundou o mundo nas últimas décadas não poupou os problemas mais fundamentais que uma comunidade democrática deve enfrentar - seja acertar as contas com seu frequentemente pouco admirável passado ou lidar com conflitos de identidade coletiva. Com a possível exceção do monitoramento judicial do processo eleitoral, nenhuma das recém-judicializadas questões é exclusiva ou intrinsecamente legal. Ainda que algumas delas possam envolver certos aspectos constitucionais significativos, não são puramente, nem mesmo primariamente, dilemas legais. Como

\footnotetext{
${ }^{103}$ Act, 2000 S.C., ch. 26 (Can.). Esse Ato “dá efeito à exigência de clareza como foi estabelecido na decisão da Suprema Corte do Canadá no caso da Consulta sobre a Secessão de Quebec". Idem.
} 
tais, devem ser resolvidas - ao menos por princípio - através de deliberação pública na esfera política. Entretanto, tribunais superiores ao redor do mundo vêm gradualmente se tornando importantes órgãos decisórios para lidar precisamente com tais dilemas. Questões fundamentais de justiça transicional, legitimidade de regimes e identidades coletivas foram formuladas como argumentos constitucionais e, assim, rapidamente encontraram seu caminho até os degraus das cortes.

\section{Por que isto está acontecendo?}

A área da megapolítica judicializada é talvez a concretização mais completa da noção do direito constitucional como política. Os exemplos discutidos até aqui realçam o fato de que nem uma estrutura constitucional favorável ao ativismo judicial, nem juízes "famintos por poder" ou tribunais constitucionais agressivos são condições suficientes para a judicialização da megapolítica. A afirmação da supremacia judicial do tipo que foi descrito neste artigo não pode acontecer ou se manter sem o suporte tácito ou explícito de atores políticos influentes. É pouco realista e até mesmo ingênuo supor que a definição de questões políticas centrais - como o conflito sobre a natureza do Canadá como uma confederação com dois povos fundadores, o problema de Israel com a pergunta "quem é judeu" e sua condição de Estado democrático e judaico, o conflito sobre o status do direito islâmico em países predominantemente mulçumanos, ou a transição democrática na África do Sul - poderia ter sido transferida para tribunais sem que essa transferência contasse com no mínimo o apoio tácito dos atores políticos relevantes nesses países. Como qualquer outra instituição política, tribunais constitucionais não operam em um vácuo institucional ou ideológico. Sua jurisprudência explicitamente política não pode ser entendida separadamente dos conflitos sociais, políticos e econômicos concretos que dão forma a um determinado sistema político. De fato, deferência política ao Judiciário e a consequente judicialização da megapolítica são partes integrais e manifestações importantes desses conflitos políticos e não podem ser entendidas isoladamente. Isso nos leva a um aspecto crítico e muitas vezes negligenciado da história - os determinantes políticos da judicialização. Uma autêntica judicialização "de baixo para cima" tem mais chances de ocorrer quando as instituições judiciais são percebidas por movimentos sociais, grupos de interesse e ativistas políticos como órgãos decisórios mais respeitáveis, imparciais e efetivos do que outras instituições governamentais consideradas "muito burocráticas" ou arenas decisórias majoritárias tidas como enviesadas. Uma judicialização da política totalmente abrangente tem, ceteris paribus, menos chances de ocorrer em uma comunidade com um sistema político unificado e assertivo, que seja capaz de limitar o Judiciário. Em tais comunidades, a esfera política pode fazer ameaças 
críveis a um Judiciário superativo. Do mesmo modo, quanto mais disfuncionais ou paralisados forem o sistema político e suas instituições decisórias em uma dada comunidade organizada como Estado de direito, mais provável será a presença de um Poder Judiciário expansivo. ${ }^{104}$ Maior fragmentação de poder entre os órgãos políticos reduz a capacidade que têm de frear os tribunais, e, consequentemente, aumenta a possibilidade de os tribunais se afirmarem. ${ }^{105}$

Do ponto de vista dos políticos, a delegação de questões políticas controversas para os tribunais pode ser um meio eficaz de transferir responsabilidade, reduzindo os riscos para eles mesmos e para o aparato institucional no qual operam. O cálculo dessa estratégia de "redirecionamento de culpa" é bastante intuitivo. Se a delegação de poderes é capaz de aumentar a legitimidade e/ou diminuir a culpa atribuída aos atores políticos pelo resultado da decisão da instituição delegada, então tal delegação pode beneficiar os atores políticos. ${ }^{106}$ No mínimo, a transferência de "abacaxis" políticos para os tribunais oferece uma saída conveniente para políticos incapazes ou desinteressados em resolver essas disputas na esfera política. Essa transferência também pode representar um refúgio para políticos que buscam evitar dilemas difíceis, nos quais não há vitória possível, e/ou evitar o colapso de coalizões de governo em estado de fragilidade ou de impasse. ${ }^{107} \mathrm{Da}$ mesma forma, a oposição pode buscar judicializar a política (por exemplo, peticionando contra políticas públicas do governo) para dificultar a vida do governo da vez. Políticos da oposição podem recorrer ao Judiciário na tentativa de aumentar sua exposição na mídia, independentemente de o resultado final da disputa ser ou não favorável. ${ }^{108}$ Com frequência, por trás da transferência para o Judiciário de questões envolvendo mudanças de regime encontraremos uma busca política por legitimidade (considere, por exemplo, a já mencionada legitimação do golpe de Estado militar pela Suprema Corte do Paquistão, em 1999). Estudos empíricos confirmam que, na maioria das democracias constitucionais, tribunais superiores têm mais legitimidade e mais apoio da opinião pública do que virtualmente todas as outras instituições políticas. ${ }^{109}$ Isso é verdade mesmo quando os tribunais se engajam em manifestações explícitas de jurisprudência política. ${ }^{110}$

A judicialização da megapolítica também pode ser alimentada por tentativas de "preservação hegemônica" de grupos sociopolíticos dominantes que estejam com receio de perder seu controle sobre o exercício do poder político. Estes gru-

\footnotetext{
${ }^{104}$ Guarnieri e Pederzoli, 2002:160-182.

${ }^{105}$ Ferejohn, 2002.

${ }^{106}$ Voigt e Salzberger, 2002.

107 Graber, 1993.

${ }^{108}$ Dotan e Hofnung, 2005.

${ }^{109}$ Fletcher e Howe, 2001; Gibson et al., 1998.

${ }^{110}$ Caldeira et al., 2003.
} 
pos e seus representantes políticos são mais propensos a delegar ao Judiciário questões estruturantes sobre a construção da nação e sobre identidades coletivas quando suas visões de mundo e preferências políticas estão sendo cada vez mais contestadas nas arenas decisórias majoritárias. ${ }^{111}$ Talvez a melhor ilustração dessa tendência possa ser encontrada em países onde o crescente suporte popular a modos teocráticos de governança coloque em xeque as preferências culturais e políticas de elites moderadas e relativamente cosmopolitas. ${ }^{112}$ Nesses cenários, uma estratégia cada vez mais comum por parte dos detentores do poder político, que representam as elites, tem sido a transferência de conflitos fundamentais sobre identidade coletiva ou sobre a relação entre "religião e Estado" para tribunais constitucionais, em detrimento da esfera política.

Dado o seu desproporcional acesso e influência sobre a arena jurídica, elites sociais em comunidades que enfrentam profundas divisões entre orientações seculares e religiosas procuram diminuir a possibilidade de contestação efetiva às suas preferências políticas seculares ocidentalizadas. O resultado tem sido uma judicialização sem precedentes de questões envolvendo identidades coletivas fundamentais, em especial... questões de religião e Estado, e a consequente emergência de tribunais constitucionais como importantes guardiães dos interesses seculares desses países.

No mesmo sentido, tem-se observado que a judicialização de questões sobre a formação de identidades coletivas é mais viável em casos de "desarmonia constitucional", causados pelo comprometimento da comunidade com valores aparentemente conflitantes, como a autodefinição de Israel como um Estado simultaneamente judaico e democrático. ${ }^{113}$ Também é mais viável quando os valores protegidos na Constituição contrastam com os valores predominantes entre a população. Consideremos, por exemplo, a separação constitucional estrita entre religião e Estado na Turquia, apesar de a grande maioria dos turcos se definir como de mulçumanos devotos.

A judicialização da política pode refletir a competitividade do mercado eleitoral de uma comunidade ou os horizontes temporais dos governantes. Segundo o modelo de "alternância eleitoral", por exemplo, quando um partido governante espera vencer diversas eleições seguidas, a probabilidade de se ter um Judiciário poderoso e independente é baixa. Porém, quando um partido governante tem baixa expectativa de permanecer no poder, torna-se mais propenso a apoiar um Judiciário poderoso, garantindo assim que o próximo partido governante não poderá

\footnotetext{
${ }^{111}$ Hirschl, 2004.

112 Idem.

${ }^{113}$ Ver Jacobsohn (2004).
} 
usar o Judiciário para fins políticos. ${ }^{114}$ Do mesmo modo, quando atores políticos são impedidos de implementar plenamente sua agenda, podem tentar vencer os obstáculos estimulando o exercício ativo do controle de constitucionalidade por um Judiciário que seja simpático à sua agenda. ${ }^{115} \mathrm{~A}$ judicialização da megapolítica pode permitir que governos imponham a comunidades enormes e heterogêneas uma política centralizadora de "tamanho único"116 (consideremos, por exemplo, o efeito uniformizador da jurisprudência constitucional de tribunais superiores em comunidades extremamente heterogêneas, como os Estados Unidos ou a União Europeia). Por fim, a transferência de "grandes questões" controversas para tribunais ou outras instituições decisórias quase profissionais e semiautônomas, tanto domésticas quanto supranacionais, pode ser vista como parte de um processo maior pelo qual elites políticas e econômicas procuram proteger a elaboração de políticas públicas das vicissitudes da política democrática, ao mesmo tempo que manifestam apoio a uma concepção schumpeteriana (ou minimalista) de demo-

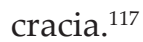

A transferência de questões fundamentais sobre identidades coletivas para os tribunais raramente leva a decisões contrárias aos interesses dos atores que optaram pela delegação de poder às instituições judiciais. Do mesmo modo, o avanço da justiça transicional através dos tribunais tem andado na melhor das hipóteses a passos pequenos e quase letárgicos. Ocasionalmente, quando provocados a se manifestar contra o establishment, os tribunais podem reagir com decisões que ameaçam alterar as relações de poder político que definem o próprio lugar do tribunal na comunidade. Na maioria dos países do novo constitucionalismo, os legisladores têm sido capazes de responder de forma efetiva a tais decisões desfavoráveis - ou de simplesmente obstruir sua implementação. Talvez a ilustração mais clara da necessidade de suporte político para a terceira face da judicialização possa ser encontrada nas inequívocas reações da esfera política contra manifestações indesejadas de ativismo judicial.

Como nos mostra a história recente da política constitucional comparada, manifestações recorrentes de intervenção judicial não solicitada na esfera política - em especial decisões inconvenientes sobre problemas políticos altamente polêmicos - levaram a significativas retaliações políticas cortando as asas dos tribunais hiperativos. Essas retaliações incluem a revisão legislativa de decisões controversas; a interferência política no processo de preenchimento das vagas nos tribunais e nas garantias inerentes ao cargo, com vistas a assegurar a indicação de

\footnotetext{
${ }^{114}$ Ver Gillman (2002).

${ }^{115}$ Whittington, 2005.

${ }^{116}$ Morton, 1995; Goldstein, 2001.

${ }^{117}$ Hirschl, 2004:211-223.
} 
juízes "obedientes" e/ou bloquear a indicação de juízes "indesejáveis"; tentativas de se "preencher o tribunal" ("court-packing") por parte dos detentores do poder político; aplicação de sanções disciplinares, impeachment ou remoção de juízes "inadequados" ou "hiperativos"; introdução de restrições à jurisdição dos tribunais, ou a "poda" dos poderes de controle de constitucionalidade. Em alguns casos (Rússia em 1993, Cazaquistão em 1995, Zimbábue em 2001 e Equador em 2004), as ações adotadas como parte da retaliação política resultaram em crises constitucionais que levaram à reconstrução ou dissolução das respectivas cortes supremas. Podemos acrescentar a essa lista respostas políticas mais sutis, e possivelmente mais letais, como a pura e simples inobservância das determinações judiciais por parte da burocracia estatal, ou a implementação vagarosa ou relutante de decisões indesejadas. ${ }^{118}$

São muitos os exemplos de situações de revisão legislativa de decisões judiciais no mundo do novo constitucionalismo. Executivos e legislativos nos EUA frequentemente reviram, neutralizaram ou driblaram decisões de cortes constitucionais. ${ }^{119}$ Em sua decisão mais famosa, no caso Mohammed Ahmad Kan $v$. Shah Bano Begum, a Suprema Corte da Índia decidiu que o direito infraconstitucional de esposas negligenciadas receberem dos maridos auxílio para sua manutenção deveria se manter independentemente de quaisquer outras disposições legais aplicáveis às partes. ${ }^{120}$ Tal decisão teve implicações sérias para a tradicional prática indiana de deixar que temas religiosos centrais fossem resolvidos pelas instituições muçulmanas. Representantes tradicionalistas da comunidade mulçumana tomaram a decisão como prova das tendências homogeneizantes dos hindus, que ameaçavam enfraquecer a identidade mulçumana. O Parlamento da Índia se curvou às maciças pressões políticas de mulçumanos conservadores e reverteu a decisão da Suprema Corte em Shah Bano através da aprovação da Lei das Mulheres Muçulmanas (proteção aos direitos de divórcio). Apesar do seu título reconfortante, a nova lei desfez a decisão da Corte, privando mulheres mulçumanas do direito de recorrer aos tribunais estatais para pedir pagamentos de pensão após o divórcio. A lei também isentou ex-maridos mulçumanos de outras obrigações pós-divórcio. Aparentemente, a Suprema Corte entendeu o recado. Ao julgar um caso sobre a constitucionalidade da Lei das Mulheres Muçulmanas, a decisão da Corte foi sensivelmente mais moderada e ambígua do que sua decisão original em Shah Bano. ${ }^{121}$

Podemos mencionar também a dura reação política e a correspondente reversão por vias legislativas da expansão dos direitos dos aborígenes promovida pela

\footnotetext{
${ }^{118}$ Conant, 2002; Rosenberg, 1991; Garret et al., 1995.

119 Peretti, 1999.

${ }^{120}$ Muhammed Ahmad Kan v. Shah Bano Begum, A.I.R., 1985, S.C. 945. Ver também Shachar (2001).

${ }^{121}$ Danial Latifi v. Union of India, A.I.R., 2001, S.C. 3958.
} 
Suprema Corte australiana. Na decisão histórica no caso Mabo v. Queensland II, a Suprema Corte abandonou o conceito jurídico de terra nullius ("terra vaga") que por séculos servira como base para a negação formal da validade das reivindicações de aborígenes - como nativos estabelecidos - a direitos de propriedade sobre a terra que ocupam, e sustentou que o título aborígene não se extinguiria com a mudança de soberania. ${ }^{122}$ No caso The Wik Peoples $v$. Queensland, a Suprema Corte sustentou que a cessão de terras pastorais a terceiros por parte do governo não necessariamente extinguiria o título nativo. ${ }^{123}$ Esta extinção só ocorreria dependendo dos termos específicos da cessão de terras pastorais e da legislação que a sustentava. As potencialmente profundas implicações redistributivas de Mabo II e Wik causaram imediata reação popular, junto com os poderosos setores agrícola e minerador, apoiados pelos governos de Queensland, da Austrália do Oeste e do Território Norte, demandando uma extinção de forma ampla e geral do título nativo de propriedade. No início de 1997, o governo conservador de John Howard cedeu deliberadamente à mobilização política contra a Corte, introduzindo no Native Title Act modificações que, para todos os fins, reverteram a decisão do caso Wik.

Consideremos também o caso de Cingapura. Respondendo prontamente a uma decisão desfavorável da Suprema Corte de Cingapura sobre o direito ao devido processo legal de dissidentes políticos detidos por "conspiração comunista para derrubar o governo", o governo de Cingapura (controlado, nas últimas quatro décadas, pelo Partido da Ação do Povo) emendou a Constituição para revogar a autoridade da Corte para exercer qualquer controle significativo da constitucionalidade de medidas governamentais de detenção preventiva. ${ }^{124}$ Em uma decisão de 1993, largamente divulgada na imprensa, o Comitê Judicial do Conselho de Estado - CJCP (Privy Council), em Londres, reverteu uma decisão da Corte Superior de Cingapura expulsando o Sr. J. B. Jeyartenam - um líder político de oposição - da Ordem dos Advogados de Cingapura. Antes da decisão no caso Jeyartenam, o status do CJCP no topo do sistema judicial de Cingapura parecia inquestionável. Mas, tão logo decidiu de forma contrária aos interesses políticos da elite dominante do país, o CJCP foi denunciado pelos oficiais governamentais como "intervencionista", "exorbitando de seu papel previsto", "alienado" das decisões locais e "fazendo política". Em questão de semanas após a decisão do CJCP, o governo de Cingapura aprovou uma emenda constitucional que aboliu de uma vez por todas a possibilidade de recurso para o CJCP. ${ }^{125}$

\footnotetext{
${ }^{122}$ Mabo v. Queensland II, 1992, 175 C.L.R. 1.

123 The Wik Peoples v. Queensland, 1996, 187 C.L.R. 1.

${ }^{124}$ Chng Suan Tze $v$. Minister of Home Affairs, 1988, 1 S.L.R. 132 (Sing.).

${ }^{125}$ Silverstein (2003). Seow, Francis T. The politics of judicial institutions in Singapore. Disponível em: <http://unpan1.un.org/intradoc/groups/public/documents/APCITY/UNPAN002727.pdf>.
} 
Percebendo a crucial importância política do Judiciário, atores políticos em outros países do novo constitucionalismo optaram por estreitar seu controle sobre o processo de indicação de juízes. No final de 1997, por exemplo, ocorreu uma séria divergência entre o primeiro-ministro paquistanês, Nawaz Sharif, e o presidente da Suprema Corte, Sajjad Ali Shah, com relação à nomeação de novos juízes para a Corte. A crise constitucional teve um fim dramático quando o presidente da Corte foi suspenso de seu cargo por membros rebeldes da própria Corte. Uma crise parecida ocorreu em janeiro de 2000, quando o general Perez Musharraf insistiu para que todos os membros da Suprema Corte jurassem lealdade à administração militar. Os juízes que se recusaram a fazê-lo foram expulsos da Corte. Reagindo ao tremor político causado pela polêmica expropriação de terras de fazendeiros brancos, em 2000, o presidente do Zimbábue, Robert Mugabe, e seu partido de governo, o Zanu (PF), depuseram em março de 2001 o juiz C. J. Gubbay, que lhes era hostil, e apontaram o juiz Chidyausiku, que os apoiava, como novo presidente da Suprema Corte. ${ }^{126}$ Mugabe também preencheu a Corte com três outros simpatizantes do Zanu (PF), de forma a assegurar o controle do partido sobre o Judiciário. ${ }^{127}$ No Egito, foram realizadas recentemente audiências disciplinares contra os juízes da Suprema Corte, Hisham El-Bastawisi e Mahmoud Mekki, por terem acusado abertamente o governo de fraude eleitoral nas eleições de novembro de 2005. ${ }^{128}$

Em 2004, a Venezuela adotou uma lei permitindo que a coalizão do presidente Hugo Chávez "limpasse e preenchesse a Suprema Corte do país". ${ }^{129}$ A lei aumentou o número de juízes de 20 para 32. Os novos juízes poderiam ser selecionados por maioria simples na Assembleia Nacional. ${ }^{130}$ A lei também estabelece novos mecanismos para a remoção de juízes. ${ }^{131} \mathrm{Um}$ deles permite a suspensão de juízes que estejam aguardando a decisão em um processo de impeachment; outro permite a rejeição e nulificação da nomeação de juízes nessa situação. ${ }^{132}$ No vizinho Equador, grandes crises políticas no final de 2004 e início de 2005 levaram à dissolução da Suprema Corte em duas ocasiões em apenas quatro meses. ${ }^{133}$ Em Trinidad e

\footnotetext{
${ }^{126}$ Matyszak, 2006:340-344.

${ }^{127}$ Idem, p. 345.

${ }^{128}$ Broken promises. The Economist, p. 48-49, Apr. 2006. O Egito tem uma história de interferências políticas na esfera judicial. O exemplo mais flagrante é o "massacre do Judiciário", de 1969, quando mais de 200 funcionários antigos da Justiça foram exonerados por questões de "excesso de independência" por um decreto presidencial.

${ }^{129}$ Human rights watch, questions and answers about Venezuela's Court-packing law (July 2004). Disponível em: <http://hrw.org/backgrounder/americas/venezuela/2004/>.

${ }^{130}$ Idem.

${ }^{131} \mathrm{Idem}$

132 Idem.

${ }^{133}$ A corte foi desfeita pelo presidente Lucio Gutierrez pela primeira vez em dezembro de 2004. Ver Ecuador dismisses Supreme Court, BBC News, 9 Dec. 2004. Disponível em: <http://news.bbc.co.uk/1/hi/ world/americas/4082521.stm>. Após ter sido restaurada em janeiro de 2005, foi desfeita novamente por uma segunda vez em abril de 2005. Ver A coup by Congress and the street, Economist, 23 Apr. 2005, p. 37. Ecuador's Congress backs Court move, N.Y. Times, 19 Apr. 2005, p. A13.
} 
Tobago, o primeiro-ministro, Patrick Manning (do Movimento Nacional, um partido majoritariamente afrotrinidense), recentemente suspendeu o presidente da Suprema Corte, Satnarine Sharma (um indotrinidense), por ter supostamente tentado ajudar o primeiro-ministro Basdeo Panday (indotrinidense e principal adversário político de Manning). ${ }^{134}$ Em abril de 1990, o presidente da Argentina, Carlos Menem, expandiu a Suprema Corte do país de cinco para nove membros e apontou sozinho os quatro novos juízes. ${ }^{135}$ Este abrupto preenchimento da Corte criou na prática uma maioria automática pró-governo. Nos últimos anos, o presidente Eduardo Duhalde e, depois dele, o presidente Nestor Kirchner, forçaram todos os membros deste bloco a sair, criando assim uma Corte mais progressista. ${ }^{136}$

O mundo pós-comunista também teve a sua cota de reações políticas antijudiciais. As indicações de vários juízes ativistas para a Corte Constitucional húngara, incluindo a do juiz László Sólyom (hoje presidente da Hungria) - proponente de um ativismo judicial baseado não no texto, mas em um "espírito" constitucional invisível -, não foram renovadas após o fim de seu termo inicial de nove anos. Ao contrário, a Corte foi preenchida com juízes novos e perceptivelmente mais formalistas, defensores da autocontenção judicial. ${ }^{137}$ A primeira Corte Constitucional do Cazaquistão foi dissolvida após a crise eleitoral de 1995, e um novo Conselho Constitucional, no estilo francês, foi introduzido. A Corte Constitucional da Albânia foi suspensa em 1998, seu presidente foi preso e foi introduzida uma emenda constitucional limitando o mandato dos juízes para nove anos.

Provavelmente, o exemplo mais óbvio quanto a esse ponto é a amplamente documentada crise constitucional de 1993 na Rússia, que incluiu a dissolução da primeira Corte Constitucional pelo presidente Boris Yeltsin. Como se sabe, o presidente Yeltsin reagiu a um envolvimento hiperativo da Corte Constitucional na esfera política russa, assinando um decreto que suspendia o funcionamento da Corte até a adoção de uma nova Constituição. Isso marcou o fim da primeira Corte Constitucional e de seu polêmico presidente, Valerii Zorkin, e deu origem ao estabelecimento da segunda Corte Constitucional. Com base em uma comparação controlada dos casos recebidos pela primeira e pela segunda cortes constitucionais, Lee Epstein, Olga Shvetsova e Jack Knight mostram que, numa clara mudança em relação à era da primeira Corte, cuja pauta era dominada por casos politicamente carregados, envolvendo federalismo e separação de poderes, a segunda Corte Constitucional russa se desviou para a "área segura" dos direitos individuais, tendendo a evitar questões de federalismo e disputas sobre separação

\footnotetext{
${ }^{134}$ Justice and the judge, The Economist, 22 July 2006, p. 40.

${ }^{135}$ Another wig falls. The Economist, 8 Oct. 2005, p. 46.

${ }^{136}$ Idem.

${ }^{137}$ Schepple, 1999.
} 
de poderes. ${ }^{138}$ Em outras palavras, respostas políticas duras ao ativismo ou a intervenções judiciais indesejadas - ou até mesmo ameaças críveis de que tais respostas são iminentes - podem influenciar os padrões decisórios judiciais. Variações dessa mesma lógica explicam cenários de comportamento judicial prudente em países tão diferentes como Argentina, ${ }^{139}$ Alemanha ${ }^{140}$ e Japão. ${ }^{141}$

\section{Conclusão}

É melhor parar com esta cascata de exemplos antes que o leitor perca a paciência. Alguns pontos devem estar mais claros agora. Primeiro, enquanto teóricos constitucionais no mundo anglo-americano se preocupam com a limitação do Poder Executivo na chamada era da "guerra contra o terror", a expansão global do poder judicial continua. Nos últimos anos, houve um aumento enorme do recurso aos tribunais para lidar com alguns dos mais fundamentais conflitos que uma comunidade pode enfrentar. A judicialização da política se estendeu muito além da hoje corrente judicialização da elaboração de políticas públicas através da jurisprudência sobre justiça processual ou sobre direitos, para englobar também a megapolítica - processos e resultados eleitorais, justiça transicional, legitimidade de regimes, prerrogativas do Executivo, identidades coletivas e processos de construção nacional. A ampla judicialização da megapolítica reflete o desaparecimento da doutrina da "questão política" e impõe um sério desafio à tradicional doutrina da separação de poderes. Essa tendência marca a transição para o que chamei de "juristocracia"142 - um fenômeno abrangente que nenhum teórico constitucional sério, nos Estados Unidos ou no exterior, pode ignorar. ${ }^{143}$

Em segundo lugar, o envolvimento sem precedentes dos tribunais em decisões políticas substantivas é difícil de ser reconciliado com alguns dos princípios fundamentais da teoria constitucional tradicional. Aqui, é importante distinguir entre assuntos primordialmente processuais, de um lado, e conflitos políticos cruciais da vida de uma nação, do outro. Se, por um lado, não há problemas sérios em atribuir aos tribunais o papel de assegurar a justiça processual em eleições, a judicialização de dilemas fundamentais de justiça transicional e legitimidade de regimes e, especialmente, de problemas fundamentais de identidade coletiva e

\footnotetext{
138 Epstein et al., 2001.

${ }^{139}$ Helmke, 2005.

${ }^{140}$ Vanberg, 2005.

${ }^{141}$ Ramseyer e Rasmusen, 2001.

${ }^{142}$ Hirschl, 2004.

${ }^{143}$ Sobre a divisão inexplicável entre a teoria constitucional e o estudo do direito e da política constitucional na vida real, ver Friedman (2005); Graber (2002).
} 
de processos de construção nacional é mais preocupante. Essas questões de megapolítica - que muitas vezes envolvem a própria definição da nação como tal - têm custos políticos muito altos e escassas diretrizes constitucionais aplicáveis à sua solução. Portanto, é difícil de entender como, ao responderem a essas questões, os juízes conseguiriam basear suas decisões em princípios ou considerações qualitativamente diferentes de princípios ou considerações típicos do processo legislativo ou dos referendos nacionais - e que podem ser mais bem definidos nesses fóruns.

A prática é igualmente problemática do ponto de vista da democracia representativa. A crescente confiança em tribunais para articular e decidir assuntos de grande importância política representa uma rejeição de responsabilidade política em larga escala, ou até mesmo uma abdicação de poder, por parte de legislaturas eleitas, cuja tarefa é assumir a responsabilidade pela tomada de decisões políticas. Pode prejudicar a própria essência da política democrática como um empreendimento que envolve a deliberação aberta - e muitas vezes controversa - entre representantes eleitos e responsabilizáveis perante os cidadãos. Afinal, a função primária das legislaturas é enfrentar e resolver problemas, e não passá-los a outros. Ao transferir autoridade decisória política para o Judiciário, esses políticos conseguem evitar a tomada de decisões difíceis ou potencialmente impopulares que fazem parte da própria tarefa pública para a qual foram eleitos - que é a de tomar, de forma responsável, decisões políticas difíceis, de princípio, mesmo quando essas decisões não são populares junto ao eleitorado. Jogando pelas regras do "redirecionamento de culpa", as legislaturas dão prioridade aos seus interesses de curto prazo (conseguir apoio eleitoral, evitando decisões difíceis e frequentemente impopulares) em detrimento da sua responsabilidade política.

Por fim, a existência de uma Corte constitucional ativa e não deferente aos poderes eleitos é condição necessária, mas não suficiente, para o ativismo judicial sistemático e para a judicialização da megapolítica. Qualquer que seja a perspectiva adotada, questões como a natureza secular do sistema político turco, a guerra na Chechênia, a definição fundamental de Israel como um "Estado judaico e democrático" ou o futuro político de Quebec e da federação canadense são questões primordialmente políticas, e não judiciais. Um incentivo à judicialização de tais questões por parte da esfera política é, portanto, uma condição no mínimo tão significativa quanto o comportamento dos tribunais e juízes para a emergência e manutenção da judicialização. Este insight lança luz sobre um tipo de falácia "tribunalizante" muito comum entre críticos do ativismo judicial, que frequentemente culpam juízes com "fome de poder" e tribunais "imperialistas" por "expropriarem" a Constituição, por serem muito assertivos e excessivamente envolvidos em decisões políticas e morais, desobedecendo assim princípios fundamentais de separação de poderes e de governança democrática. Como os exemplos discutidos neste artigo ilustram, essa imagem de tribunais e juízes constitucionais como os 
principais culpados pela abrangente judicialização da política no mundo é uma narrativa simplista demais; a judicialização da megapolítica e, de modo mais geral, a transição para a juristocracia é, sobretudo, um fenômeno político, e não jurídico. E é sob esse prisma que ele deve ser estudado.

\section{Referências}

ALTER, Karen J. Establishing the supremacy of European law: the making of an international rule of law in Europe. Oxford: Oxford University Press, 2001.

BROWN, Nathan J. Islamic constitutionalism in theory and practice. In: CORTAN, Eugene; SHERIF, Adel Omar (Eds.). Democracy, the rule of law and Islam. London: Kluwer Law International, 1999.

CALDEIRA, Gregory et al. The Supreme Court and the U.S. presidential election of 2000. British J. Pol. Sci., v. 33, n. 535, 2003.

CHARLES, R. The rights revolution: lawyers, activists, and Supreme Courts in comparative perspective. Chicago: The University of Chicago Press, 1998.

CONANT, Lisa. Justice contained: law and politics in the European Union. New York: Cornell University Press, 2002.

COTRAN, E.; MALLAT, C. (Eds.). Yearbook of Islamic \& Middle Eastern Law. The Hague: Kluwer Law International, 1996. p. 178-180.

DOTAN, Yoav; HOFNUNG, Menachem. Legal defeats-political wins: why do elected representatives go to Court? Comp. Pol. Stud., n. 75, 2005.

DURKHEIM, Emile. The division of labor in society. The Free Press, 1964.

EPP, Charles R. The rights revolution: lawyers, activists, qnd supreme courts in comparative perspective. Chicago: The University of Chicago Press, 1998.

EPSTEIN, Lee et al. The role of constitutional courts in the establishment and maintenance of democratic systems of government. Law $\mathcal{E}$ Soc'y Rev., v. 35, n. 117, 2001.

FEREJOHN, John. Judicializing politics, politicizing law. Law E Contemp. Probs., v. 65, n. $41,2002$.

FLETCHER, Joseph F.; HOWE, Paul. Public opinion and Canada's Courts. In: HOWE, Paul; RUSSELL, Peter (Eds.). Judicial power and Canadian democracy. Montreal: McGill Queen's for the Institute for Research on Public Policy, 2001. p. 255296. 
FRIEDMAN, Barry. The politics of judicial review. Tex. L. Rev., v. 84, n. 257, 2005.

GABR, Hatem Aly Labib. The interpretation of article two of the Egyptian Constitution by the Supreme Constitutional Court. In: BOYLE, Kevin; SHERIF, Adel Omar (Eds.). Human rights and democracy: the role of the Supreme Constitutional Court of Egypt, 1996.

GARRETT, Geoffrey et al. The politics of legal integration in the European Union. Int'l Org., v. 49, n. 171, 1995.

GIBSON, James L. et al. On the legitimacy of high courts. Am. Pol. Sci. Rev., v. 92, n. 343, 1998.

GILLMAN, Howard. How political parties can use the Courts to advance their agendas: federal courts in the United States. Am. Pol. Sci. Rev., v. 96, n. 511, p. 18751.891, 2002.

GLENDON, Mary Ann. Rights talk: the impoverishment of political discourse. New York: The Free Press, 1991.

GOLDSTEIN, Judith et al. (Eds.). Legalization and world politics. Ithaca: Cornell University Press, 2001.

GOLDSTEIN, Leslie Friedman. Constituting federal sovereignty: the European Union in comparative context. Baltimore: Johns Hopkins University Press, 2001.

GRABER, Mark A. The nonmajoritarian difficulty: legislative deference to the Judiciary. Stud. in Am. Pol. Dev., v. 7, n. 35, 1993.

. Constitutional politics and constitutional theory: a misunderstood and neglected relationship. Law \& Soc. Inquiry, v. 27, n. 309, 2002.

GUARNIERI, Carlo; PEDERZOLI, Patrizia. The power of judges: a comparative study of courts and democracy. New York: Oxford University Press, 2002.

HABERMAS, Jürgen. Law as medium and law as institution. In: TEUBNER, Gunther (Ed.). Dilemmas of Law in the Welfare State. Berlin, 1986.

HASEN, Richard. A critical guide to Bush v. Gore scholarship. Ann. Rev. Pol. Sci., n. 297, 2004.

HELMKE, Gretchen. Courts under constraints: judges, generals, and presidents in Argentina. New York: Cambridge University Press, 2005.

HIRSCHL, Ran. Resituating the judicialization of politics: Bush $v$. Gore as a global trend. Can. J.L. E Juris, v. 15, n. 191, 2002.

. Towards juristocracy: the origins and consequences of the new constitutionalism. Cambridge: Harvard University Press, 2004. 
. Constitutionalism, judicial review, and progressive change: a rejoinder to McClain and Fleming. Tex. L. Rev., v. 84, n. 471, p. 485-502, 2005.

HOGG, Chris. Taiwan Court to rule on election. BBC News Online. Nov. 2004. Disponível em: <http://news.bbc.co.uk/2/hi/asia-pacific/3978921.stm >.

ISSACHAROFF, Samuel et al. The law of democracy: legal structure of the political process. Westbury: Foundation Press, 1998.

JACOBSOHN, Gary J. The permeability of constitutional borders. Tex. L. Rev., v. 82, n. 1763, 2004.

KERR, Rachel. The international criminal tribunal for the former Yugoslavia: an exercise in law, politics, and diplomacy. Oxford: Oxford University Press, 2004.

KOMMERS, Donald P. The constitutional jurisprudence of the Federal Republic of Germany. Durham: Duke University Press, 1997.

LUHMANN, Niklas. A sociological theory of law. Routledge e Kegan Paul, 1985.

MAINE, Henry Sumner. Ancient law. [1886]. New Brunswick: Transaction Publishers, 2001.

MATYSZAK, Derek. Creating a complaint Judiciary in Zimbabwe. In: RUSSELL, P. (Ed.). Appointing judges in an age of judicial power dilemmas of law in the Welfare State. p. 340-344, 2006.

MILLER, Russell A. Lords of democracy: the judicialization of "pure politics" in the United States and Germany. Wash. \& Lee L. Rev., n. 587, 2004.

MORTON, F. L. The effect of the charter of rights on Canadian federalism. Publius, v. 25, n. $173,1995$.

PERETTI, Terri Jennings. In defense of a political Court. Princeton: Princeton University Press, 1999.

PILDES, Richard H. The Supreme Court, 2003 term - foreword: the constitutionalization of democratic politics. Harv. L. Rev., v. 118, n. 29, 2004.

POMERANZ, William E. Judicial review and the Russian Constitutional Court: the Chechen case. Rev. Cent. \& E. Eur. L., v. 23, n. 9, 1997.

QUINT, Peter E. Judging the past: the prosecution of East German border guards and the GDR chain of command. Rev. Pol., v. 61, n. 303, 1999.

RAMSEYER, J. Mark; RASMUSEN, Eric B. Why are Japanese judges so conservative in politically charged cases? Am. Pol. Sci. Rev., v. 95, n. 331, 2001.

ROMANO, Cesare P. R. The proliferation of international judicial bodies: the pieces of the puzzle. N.Y.U. J. Int'l Law \& Pol., v. 31, p. 109, 1999. 
ROSENBERG, Gerald N. The hollow hope: can courts bring about social change? Chicago: Chicago University Press, 1991.

. Judicial independence and the reality of political power. Rev. Pol., v. 54, n. $369,1992$.

SCHABAS, William. An introduction to the international criminal court. Cambridge: Cambridge University Press, 2004.

SCHEINGOLD, Stuart A. The politics of rights: lawyers, public policy, and political change. 2. ed. Ann Arbor: University of Michigan Press, 2004.

SCHEPPLE, Kim Lane. The new Hungarian Constitutional Court. E. Eur. Const. Rev., v. 8, n. 81, 1999.

SCHWARTZ, Herman. The struggle for constitutional justice in post-communist Europe. Chicago: Chicago University Press, 2000.

SHACHAR, Ayelet. Multicultural jurisdictions: cultural differences and women's rights. Cambridge: Cambridge University Press, 2001.

SHAPIRO, Martin; SWEET, Alec Stone. On law, politics and judicialization. Oxford: Oxford University Press, 2002.

SIEDER, Rachel et al. (Eds.). The judicialization of politics in Latin America. New York: Palgrave MacMillan, 2005.

SILVERSTEIN, Gordon. Globalization and the rule of law: a machine that runs of itself? Int'l J. of Const. Law, v. 1, n. 427, p. 439-440, 2003.

SLAUGHTER, Anne-Marie. Judicial globalization. Va. J. Int'l L., 2000.

SÓLYOM, László; BRUNNER, Georg (Eds.) Constitutional Judiciary in a new democracy: the Hungarian Constitutional Court. Ann Arbor: University of Michigan Press, 2000. p. 322-332.

SWEET, Alec Stone. Governing with judges: constitutional politics in Europe. 2000.

; BRUNELL, Thomas L. Constructing a supranational Constitution: dispute resolution and governance in the European Cimmunity. Am. Pol. Sci. Rev., n. 92, p. 63-91, 1998.

TATE, Neal C.; VALLINDER, Torbjörn (Eds.). The global expansion of judicial power. New York: New York: University Press, 1995.

TEUBNER, Gunther. (Ed.). Juridification of social spheres. Berlin; New York: de Gruyter, 1987.

TOCQUEVILLE, Alexis de. Democracy in America. 10. ed. Vintage Books, 1961. 
TUSHNET, Mark. Law and prudence in the law of justiciability: the transformation and disappearance of the political question doctrine. N.C. L. Rev., v. 80, n. 1.203, 2002.

VANBERG, Georg. The politics of constitutional review in Germany. Cambridge: Cambridge University Press, 2005.

VOIGT, Stefan; SALZBERGER, Eli M. Choosing not to choose: when politician choose to delegate powers. Kyklos, v. 55, n. 289, p. 294-295, 2002.

WALDRON, Jeremy. Judicial power and popular sovereignty. In: GRABER, Mark A.; PERHAC, Michael. (Eds.). Marbury versus Madison: documents and commentary. Washington, D.C.: CQ Press, 2002.

WEBER, Max. Economy and society: an outline of interpretive sociology. In: ROTH, Guenther; WITTICH, Claus. (Eds.). Bedminster Press, 1968.

WEILER, Joseph H. H. The Constitution of Europe: "Do the new clothes have an emperor?" And other essays on European integration. Cambridge: Cambridge University Press, 1999.

WHITTINGTON, Keith E. "Interpose your friendly hand": political supports for the exercise of judicial review by the United States Supreme Court. Am. Pol. Sci. Rev., v. 99, n. 583, 2005.

ZAMORA, Stephen et al. Mexican law. Oxford: Oxford University Press, 2004. 